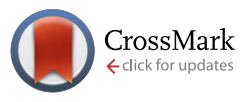

Cite this: Med. Chem. Commun., $2015,6,1093$

Received 23rd February 2015, Accepted 14th April 2015

DOI: $10.1039 / c 5 m d 00079 c$

www.rsc.org/medchemcomm

\section{Novel indole-based sigma-2 receptor ligands: synthesis, structure-affinity relationship and antiproliferative activity $\uparrow$}

\author{
Fang Xie, ${ }^{\text {ab }}$ Torsten Kniess, ${ }^{\mathrm{b}}$ Christin Neuber, ${ }^{\mathrm{b}}$ Winnie Deuther-Conrad, ${ }^{\mathrm{b}}$ \\ Constantin Mamat, ${ }^{b c}$ Brian P. Lieberman, ${ }^{d}$ Boli Liu, ${ }^{a}$ Robert H. Mach, ${ }^{d}$ Peter Brust, ${ }^{b}$ \\ Jörg Steinbach, ${ }^{\text {bc }}$ Jens Pietzsch ${ }^{\text {bc }}$ and Hongmei Jia*a
}

\begin{abstract}
We report the synthesis and biological evaluation of a series of indole-based $\sigma_{2}$ receptor ligands derived from siramesine. In vitro competition binding assays showed that these analogues possessed high to moderate affinity and selectivity for $\sigma_{2}$ receptors. Structure-affinity relationship analyses of these indole-based $\sigma_{2}$ receptor ligands were performed. In the 3-(4,5-dimethythiazol-2-yl)-2,5-diphenyltetrazolium bromide (MTT) assay, $1 \mathrm{a}$ and $1 \mathrm{~b}$ displayed significant and comparable antiproliferative activity in DU145, MCF7 and C6 cells to siramesine. In cell cycle analyses, compounds $1 \mathrm{a}, 1 \mathrm{~b}$ and siramesine were found to induce a $\mathrm{G}_{1}$ phase cell cycle arrest in DU145 cells using flow cytometry. The combination of 5,6-dimethoxyisoindoline scaffold and $\mathrm{N}$-(4-fluorophenyl)indole moiety was identified as a new $\sigma_{2}$ receptor ligand deserving further investigation as an antitumor agent.
\end{abstract}

\section{Introduction}

Two subtypes of sigma $(\sigma)$ receptors, termed $\sigma_{1}$ and $\sigma_{2}$, have been identified. ${ }^{1}$ Both subtypes display different distributions in the central nervous system and peripheral organs. The $\sigma_{1}$ receptor contains 223 amino acids with two transmembrane regions. $^{2,3}$ It functions as "ligand-operated receptor chaperone" and regulates various ion channels, G protein-coupled receptors, lipids, and other signaling proteins. ${ }^{4,5}$ In contrast, the $\sigma_{2}$ receptor has not been cloned so far, and its molecular weight was estimated to be $21.5 \mathrm{kD}$. Recently, progesterone receptor membrane component 1 (PGRMC1) was reported as the putative $\sigma_{2}$ receptor binding site. ${ }^{6}$

It is interesting that both subtypes are expressed in a variety of human and rodent tumor cell lines. ${ }^{7,8}$ However, the expression of the $\sigma_{2}$ receptor was found to be higher than that of the $\sigma_{1}$ receptor. In proliferating tumor cells, the density of the $\sigma_{2}$ receptor was about 8 - to 10 -fold higher than

\footnotetext{
${ }^{a}$ Key Laboratory of Radiopharmaceuticals (Beijing Normal University), Ministry of Education, College of Chemistry, Beijing Normal University, Beijing 100875, China. E-mail: hmjia@bnu.edu.cn; Fax: +86 10 58808891; Tel: +86 1058808891

${ }^{b}$ Helmholtz-Zentrum Dresden-Rossendorf, Institute of Radiopharmaceutical Cancer Research, POB 510119, D-01314 Dresden, Germany

${ }^{c}$ Technische Universität Dresden, Department of Chemistry and Food Chemistry, D-01062 Dresden, Germany

${ }^{d}$ Department of Radiology, Perelman School of Medicine, University of

Pennsylvania, 231 S. 34th Street, Philadelphia, PA 19104, USA

$\dagger$ Electronic supplementary information (ESI) available. See DOI: 10.1039/ c5md00079c
}

that in quiescent tumor cells. ${ }^{9-11}$ Moreover, $\sigma_{2}$ receptor ligands can rapidly internalize into tumor cells and activate apoptosis via multiple pathways. ${ }^{12-15}$ Thus, the $\sigma_{2}$ receptor may both serve as a receptor-based biomarker to distinguish different proliferative states of solid tumors and as a promising target for the treatment of cancer. ${ }^{16}$

In the past decades, morphans, indoles (siramesine analogues), granatanes, flexible benzamides and $\mathrm{N}$-cyclohexylpiperazines have been reported to serve as selective $\sigma_{2}$ receptor ligands. ${ }^{17}$ Among these ligands, siramesine (also known as Lu-28-179) and its analogues, conformationally flexible amines such as RHM-1, and PB28 analogues were more extensively investigated. ${ }^{17}$ Their structures are presented in Fig. 1. Although clinical trials of siramesine for the treatment of depression and anxiety were paused in 2002, it proved to be non-toxic and well tolerated in humans. Most importantly, siramesine was demonstrated to induce cell death in many tumorigenic and immortalized cells via different apoptotic pathways. ${ }^{12-14,18}$ To obtain selective $\sigma_{2}$ receptor ligands with antiproliferative activity, we used siramesine as the lead compound to design a series of novel indole-based compounds. It was reported that the indole residue and the butyl chain between the indole and the spirocyclic piperidine moieties were important to maintain the $\sigma_{2}$ receptor selectivity for siramesine derivatives. ${ }^{17}$ We introduced different functional groups to develop new $\sigma_{2}$ receptor ligands. Moreover, we also introduced the substituents with fluorine atom to find PET radiotracers for $\sigma_{2}$ receptor tumor imaging. The design concept is shown in Fig. 2. First, by keeping the 4-fluorophenyl ring at the indole $\mathrm{N}$-atom and the butyl chain constant, 
<smiles>[R1][M]CCCCNC(=O)c1cc(C)ccc1OC</smiles><smiles>COc1cccc2c1CCCC2CCCN1CCN(C2CCCCC2)CC1</smiles>

Fig. 1 The structures of siramesine, RHM-1 and PB28.<smiles>[R]CCCCc1cn(CCF)c2ccccc12</smiles><smiles>C=CCc1cn(-c2ccccc2F)c2ccccc12</smiles><smiles>[R]CCCCc1cn(-c2ccc(I)cc2)c2ccccc12</smiles><smiles>[R]CCCCc1cn(-c2ccc(F)cc2)c2ccccc12</smiles><smiles>[Y]N1CCc2cc(OC)c(OC)cc2C1</smiles>

B:<smiles>COc1cc2c(cc1OC)CN(C)C2</smiles>

C:<smiles>CN1CCC(C#N)(c2ccccc2)CC1</smiles>

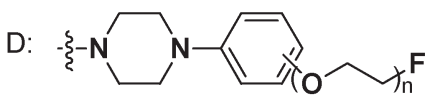<smiles>CN1CCC2(CC1)OCc1ccccc12</smiles><smiles>[R]CCCCC(=O)c1ccc(F)cc1</smiles>

Fig. 2 Design concept of the indole-based compounds.

$3 H$-spiro(2-benzofuran-1,4'-piperidinyl) moiety was replaced by different pharmacophores including $\sigma_{1}$ preferred group $\mathrm{C}$ and $\sigma_{2}$ preferred group A, B, or D (1). Secondly, the 4-fluorophenyl ring at the indole $\mathrm{N}$-atom was replaced by a 2-fluoroalkyl group (2). As a third approach, both the 4-fluorophenyl ring at the indole $\mathrm{N}$-atom and the $3 \mathrm{H}$-spiro(2-benzofuran-1,4'-piperidinyl) moiety were modified (3). Fourth, 4-fluorophenyl was replaced by the 4 -iodophenyl group, while the $3 H$-spiro(2-benzofuran-1,4'piperidinyl) moiety was replaced by $\mathrm{C}$ (4). Finally, the indole core was replaced by 4 -fluoro-benzophenone (5). Moreover, the structure-affinity relationships (SAR) of these analogues for $\sigma_{2}$ receptors were analyzed. The 3-(4,5-dimethythiazol-2-yl)-2,5- diphenyltetrazolium bromide (MTT) assay was performed to investigate the antiproliferative activity of the most potent ligands. In order to further support this, cell cycle analysis was carried out to examine the effects of these potent compounds on the cell cycle progression using flow cytometry in DU145 cells.

\section{Results and discussion}

\subsection{Chemistry}

The synthetic routes of fluorophenylindole derivatives $\mathbf{1 a}-\mathbf{1 g}$ are depicted in Scheme 1. All compounds in this series were prepared from the key bromobutyl derivative $\mathbf{6}$. Compounds $6,{ }^{19}$ 

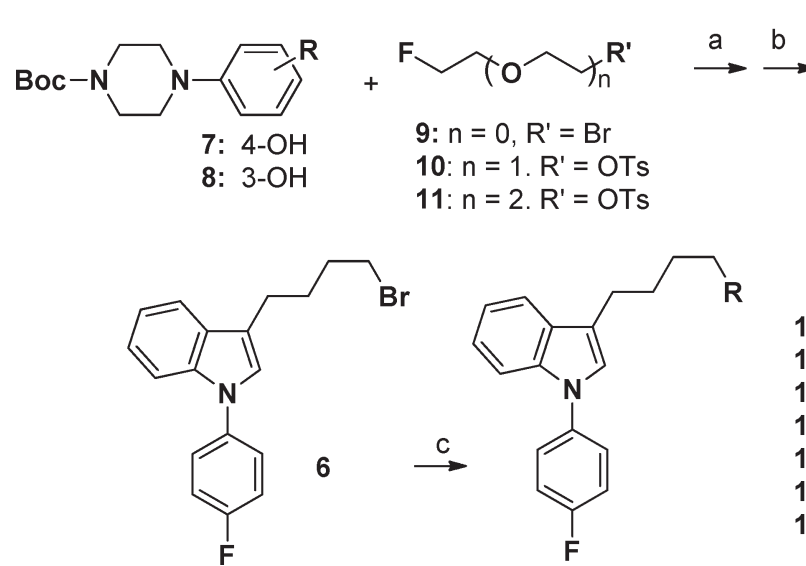

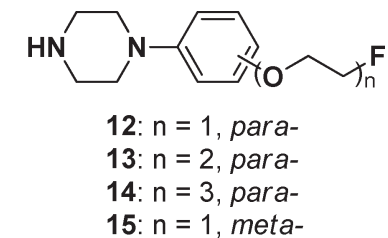

1a: $R=A$

$1 \mathrm{~b}: \mathrm{R}=\mathrm{B}$

1c: $R=C$

$1 \mathrm{~d}: \mathrm{R}=\mathrm{D}, \mathrm{n}=1$, para-

1e: $R=D, n=2$, para-

1f: $R=D, n=3$, para-

1g: $R=D, n=1$, meta-

Scheme 1 Synthesis of fluorophenylindole derivatives 1a-1g. Reagents and conditions: (a) $\mathrm{K}_{2} \mathrm{CO}_{3}, \mathrm{Nal}, \mathrm{DMF}, 105{ }^{\circ} \mathrm{C}$, overnight, 64-92\%; (b) TFA, $\mathrm{CH}_{2} \mathrm{Cl}_{2}, 0{ }^{\circ} \mathrm{C}, 2 \mathrm{~h}$; (c) $\mathrm{K}_{2} \mathrm{CO}_{3}, \mathrm{Nal}, \mathrm{CH}_{3} \mathrm{CN}, 80{ }^{\circ} \mathrm{C}, 4 \mathrm{~h}$, for 1a, 6,7-dimethoxy-1,2,3,4-tetrahydroisoquinoline (16), 52\%; for 1b, 5,6dimethoxyisoindoline (17), 52\%; for 1c, 4-phenylpiperidine-4-carbonitrile (18), 42\%; for 1d-1g, 12-15, 16-83\%.

$12,^{20} 15^{20}$ and $19^{21}$ were synthesized according to the method reported in the literature. Compound 7 or 8 reacted with intermediates 9-11 under basic conditions, followed by deprotection to obtain compounds 12-15 with yields of 56-95\%. $\mathrm{N}$-Alkylation of 6,7-dimethoxy-1,2,3,4-tetrahydroisoquinoline (16), 5,6-dimethoxyisoindoline (17), 4-phenylpiperidine-4-carbonitrile (18) or 12-15 with compound 6 provided compounds 1a, 1b, 1c, or $1 \mathrm{~d}-1 \mathrm{~g}$, respectively, with yields of $29-84 \%$.

The synthetic route of compound 2 is presented in Scheme 2. Protection of compound 19 with TBDMS chloride, followed by $\mathrm{N}$-alkylation of compound 20 with 2-bromoethanol and tosylation of compound 21 with $p$-TsCl provided compound 22. Deprotection of TBDMS and fluorination of compound 22 with TBAF by a one-pot reaction afforded compound 23 with yield of $56 \%$. Tosylation of compound 23 led to compound 24 , which reacted with $3 \mathrm{H}$-spiro[2-benzofuran1,4'-piperidine] (25) to obtain target compound 2.

The synthetic routes of compounds $3 \mathbf{a}-\mathbf{3} \mathbf{c}$ are depicted in Scheme 3. Reduction of indole-3-acetic acid (26) and indole-3propanoic acid (27) with $\mathrm{LiAlH}_{4}$ gave the corresponding alcohols 28 and 29 in $86 \%$ and $79 \%$ yield, respectively. Alkylation with 1,4-dibromobutane yielded 30 and 31, followed by fluorination with DAST to obtain 32 and 33. Finally, compound 32 or 33 reacted with intermediate 16 to provide $3 a$ and 3 b, respectively. Compound 32 reacted with 25 to obtain $3 c$.

The synthetic routes of compounds 4 and 5 are depicted in Scheme 4. Synthesis of compound 4 was similar to that of compound 1c. Ullmann reaction between compound 19 and 1,4-diiodobenzene ${ }^{22}$ instead of the 4-fluorophenyl residue provided 34 which was subsequently treated with $\mathrm{PBr}_{3}$ to yield 35. Finally, reaction between 35 and intermediate 18 provided target compound 4 . $\mathrm{N}$-Alkylation of intermediate 16 with 5-bromo-1-(4-fluorophenyl)pentan-1-one (36) gave compound 5 with yield of $62 \%$.

\subsection{In vitro radioligand competition studies and structure- affinity relationship analyses}

The affinities of the indole-based analogues for the $\sigma_{1}$ and $\sigma_{2}$ receptors were determined by radioligand competition binding
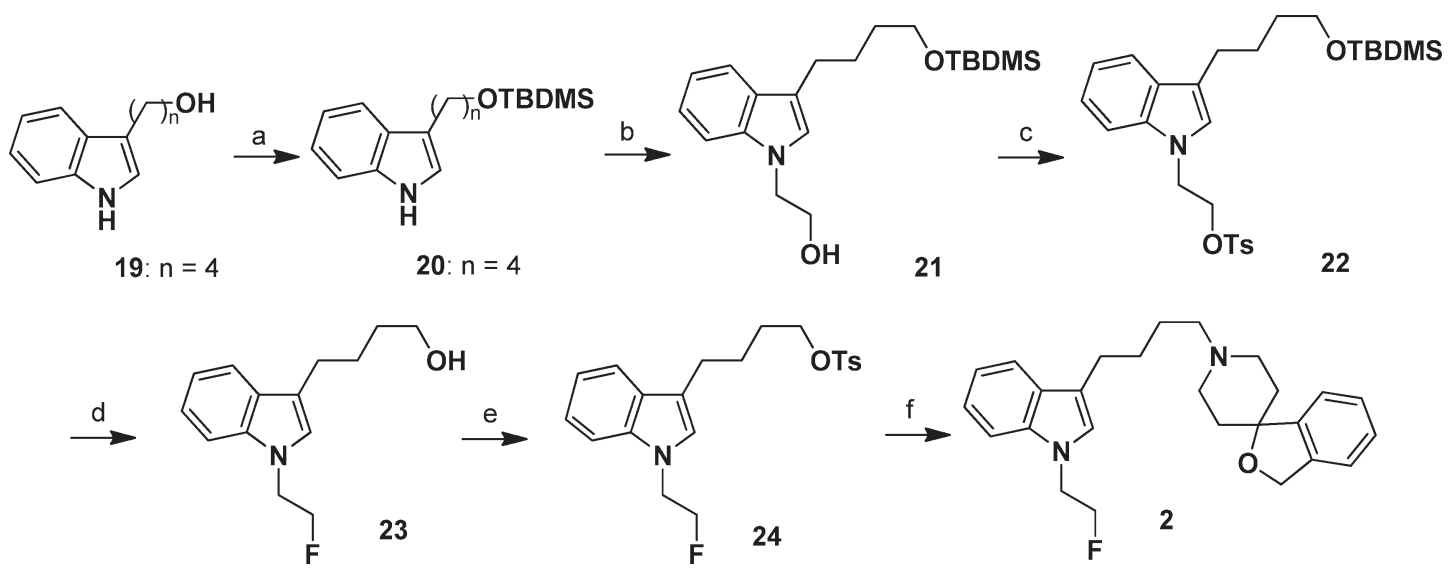

Scheme 2 Synthetic route of compound 2. Reagents and conditions: (a) TBDMSCl, imidazole, $\mathrm{CH}_{2} \mathrm{Cl}_{2}$, r.t., 2 h, 84\%; (b) Ar atmosphere, $110{ }^{\circ} \mathrm{C}$, 2-bromoethanol, $\mathrm{NaH}, \mathrm{DMF}$, overnight, 37\%; (c) p-TsCl, DIPEA, DMAP, THF, r.t., 2 h, 18\%; (d) TBAF, THF, r.t., overnight, 56\%; (e) p-TsCl, DIPEA, DMAP, THF, r.t., $2 \mathrm{~h}, 44 \%$; (f) $\mathrm{K}_{2} \mathrm{CO}_{3}, \mathrm{Nal}, \mathrm{CH}_{3} \mathrm{CN}, 3 \mathrm{H}$-spiro[2-benzofuran-1,4'-piperidine] (25), $80{ }^{\circ} \mathrm{C}, 4 \mathrm{~h}, 38 \%$. 
<smiles>O=C(O)Cc1c[nH]c2ccccc12</smiles><smiles>CC(C)C(=O)c1c[nH]c2ccccc12</smiles>

29: $n=3$

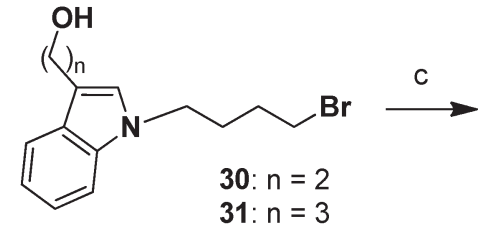

30: $n=2$
31: $n=3$<smiles>[R]CCCCn1cc([Al]F)c2ccccc21</smiles>

Scheme 3 Synthetic routes of compounds 3a-3c. Reagents and conditions: (a) Ar atmosphere, $0{ }^{\circ} \mathrm{C}, \mathrm{LiAlH}_{4}$, anhydrous THF, $4 \mathrm{~h}, 86 \%$ for $28,79 \%$ for 29; (b) Ar atmosphere, $110{ }^{\circ} \mathrm{C}, 1,4$-dibromobutane, NaH, DMF, overnight, $19 \%$ for $30,34 \%$ for 31 ; (c) Ar atmosphere, $-78{ }^{\circ} \mathrm{C}, \mathrm{DAST}$, anhydrous $\mathrm{CH}_{2} \mathrm{Cl}_{2}, 2 \mathrm{~h}, 58 \%$ for $32,87 \%$ for 33 ; (d) $\mathrm{K}_{2} \mathrm{CO}_{3}, \mathrm{Nal}, \mathrm{CH}_{3} \mathrm{CN}, 80{ }^{\circ} \mathrm{C}, 4 \mathrm{~h}$, for $3 \mathrm{a}, 32,16,43 \%$; for $3 \mathrm{~b}, 33,16,36 \%$; for $3 \mathrm{c}, 32,25,41 \%$.<smiles>[R]CCCCc1cn(-c2ccc(I)cc2)c2ccccc12</smiles><smiles>COc1cc2c(cc1OC)CN(CCCCC(=O)c1ccc(F)cc1)CC2</smiles>

Scheme 4 Synthetic routes of compounds 4 and 5. Reagents and conditions: (a) 1,4-diiodobenzene, $\mathrm{K}_{2} \mathrm{CO}_{3}, \mathrm{copper}$ powder, $\mathrm{DMF}, 120{ }^{\circ} \mathrm{C}, 5 \mathrm{~h}$, 23\%; (b) $\mathrm{PBr}_{3}$, anhydrous $\mathrm{CH}_{2} \mathrm{Cl}_{2},{ }^{\circ} \mathrm{C}, 2 \mathrm{~h}, 58 \%$; (c) $\mathrm{K}_{2} \mathrm{CO}_{3}, \mathrm{Nal}, \mathrm{CH}_{3} \mathrm{CN}, 18,80{ }^{\circ} \mathrm{C}, 4 \mathrm{~h}, 49 \%$. (d) $\mathrm{K}_{2} \mathrm{CO}_{3}, \mathrm{Nal} \mathrm{CH}_{3} \mathrm{CN}, 16,80{ }^{\circ} \mathrm{C}, 4 \mathrm{~h}, 62 \%$.

assays as reported previously. ${ }^{23}(+)-\left[{ }^{3} \mathrm{H}\right]$ Pentazocine and $\left[{ }^{3} \mathrm{H}\right] 1,3-$ di-o-tolyl-guanidine (in the presence of $10 \mu \mathrm{M}$ dextrallorphan) were used as radioligands for the $\sigma_{1}$ and $\sigma_{2}$ receptors, respectively. The results are listed in Table 1.

It was reported that siramesine possessed a subnanomolar affinity $\left(\mathrm{IC}_{50}\left(\sigma_{2}\right)=0.12 \mathrm{nM}\right)$ and high subtype selectivity $\left(\mathrm{IC}_{50}\left(\sigma_{1}\right)=17 \mathrm{nM}, \mathbf{I C}_{50}\left(\sigma_{1}\right) / \mathbf{I C}_{50}\left(\sigma_{2}\right)=140\right)$ for $\sigma_{2}$ receptors. ${ }^{24}$ More recently, Niso et al. revealed its high affinity $\left(K_{\mathrm{i}}\left(\sigma_{2}\right)=\right.$ $12.6 \mathrm{nM})$ and low subtype selectivity $\left(K_{\mathrm{i}}\left(\sigma_{1}\right) / K_{\mathrm{i}}\left(\sigma_{2}\right)=0.83\right){ }^{25}$ For comparison, we also synthesized this compound and our sample showed nanomolar affinity $\left(K_{\mathrm{i}}\left(\sigma_{2}\right)=3.08 \mathrm{nM}\right)$ and low subtype selectivity $\left(K_{\mathrm{i}}\left(\sigma_{1}\right) / K_{\mathrm{i}}\left(\sigma_{2}\right)=1.52\right)$, which is in good agreement with that reported by Niso et al.

Keeping the 4-fluorophenyl ring at the indole $\mathrm{N}$-atom and the butyl chain constant, replacement of $3 H$-spiro(2-benzofuran1,4'-piperidinyl) moiety with $\sigma_{1}$ preferred group $\mathrm{C}$ retained the low nanomolar affinity and non-selectivity for $\sigma_{2}$ receptors (1c vs. siramesine). On the other hand, replacement with $\sigma_{2}$ preferred group A, B, or D decreased the affinity for $\sigma_{2}$ receptors but increased the subtype selectivity. Compounds 1a, 1b, 1d and $1 \mathrm{~g}$ showed moderate affinity $\left(K_{\mathrm{i}}\left(\sigma_{2}\right)=48.4-68 \mathrm{nM}\right)$ and increased selectivity $\left(K_{\mathrm{i}}\left(\sigma_{1}\right) / K_{\mathrm{i}}\left(\sigma_{2}\right)=4.8-10.7\right)$ compared to siramesine. Compound 1d with substitution at the para-position of the phenyl ring in group D showed comparable affinity to compound $1 \mathrm{~g}$ with substitution at the meta-position but had a somewhat higher subtype selectivity. Substitution at the para-position with an increased length of the fluorooligoethoxylated chain $(n=2,3)$ dramatically decreased the affinities for $\sigma_{1}$ and $\sigma_{2}$ receptors (1e and 1f). In the literature, compound 1a was reported to possess nanomolar affinity $\left(K_{\mathrm{i}}\left(\sigma_{2}\right)=5.34 \mathrm{nM}\right)$ and high subtype selectivity $\left(K_{\mathrm{i}}\left(\sigma_{1}\right) / K_{\mathrm{i}}\left(\sigma_{2}\right)=260\right)$ for $\sigma_{2}$ receptors. ${ }^{25}$ However, our sample displayed only moderate affinity $\left(K_{\mathrm{i}}\left(\sigma_{2}\right)=49.2 \mathrm{nM}\right)$ and selectivity $\left(K_{\mathrm{i}}\left(\sigma_{1}\right) / K_{\mathrm{i}}\left(\sigma_{2}\right)=10.8\right)$. The above discrepancy may result from the different experimental conditions employed by different groups. It is interesting to note that compound 1b with the 5,6-dimethoxyisoindoline moiety displayed comparable affinity and selectivity to compound 
Table 1 Binding affinities of indole-based analogues for $\sigma_{1}$ and $\sigma_{2}$ receptors ${ }^{a}$

\begin{tabular}{|c|c|c|c|}
\hline Compound & $K_{\mathrm{i}}\left(\sigma_{1}\right)(\mathrm{nM})$ & $K_{\mathrm{i}}\left(\sigma_{2}\right)(\mathrm{nM})$ & $K_{\mathrm{i}}\left(\sigma_{1}\right) / K_{\mathrm{i}}\left(\sigma_{2}\right)$ \\
\hline $1 \mathrm{a}$ & $530.8 \pm 181.1$ & $49.2 \pm 11.7$ & 10.8 \\
\hline $1 a^{b}$ & $1390 \pm 20$ & $5.34 \pm 1.22$ & 260 \\
\hline $1 b$ & $255.6 \pm 14.8$ & $53.8 \pm 1.4$ & 4.8 \\
\hline 1c & $2.58 \pm 0.82$ & $3.03 \pm 0.75$ & 0.9 \\
\hline 1d & $614 \pm 137$ & $68.0 \pm 0.04$ & 9.0 \\
\hline $1 e$ & $1110 \pm 252$ & $458 \pm 51$ & 2.4 \\
\hline 1f & $2158 \pm 404$ & $1879 \pm 11$ & 1.1 \\
\hline $1 \mathrm{~g}$ & $257 \pm 62.8$ & $48.4 \pm 2.65$ & 5.3 \\
\hline 2 & $246 \pm 59.4$ & $44.0 \pm 28.1$ & 5.6 \\
\hline $3 \mathbf{a}$ & $493.5 \pm 84.1$ & $27.5 \pm 0.7$ & 17.9 \\
\hline $3 \mathbf{b}$ & $262.5 \pm 62.9$ & $28.5 \pm 4.9$ & 9.2 \\
\hline $3 c$ & $11.0 \pm 0.5$ & $29.8 \pm 1.6$ & 0.4 \\
\hline 4 & $386 \pm 94$ & $18.5 \pm 5.7$ & 20.9 \\
\hline 5 & $16.6 \pm 1.1$ & $12.4 \pm 0.6$ & 1.3 \\
\hline Siramesine & $4.69 \pm 2.36$ & $3.08 \pm 0.68$ & 1.5 \\
\hline Siramesine $^{b}$ & $10.5 \pm 2.6$ & $12.6 \pm 0.1$ & 0.8 \\
\hline Siramesine ${ }^{c}$ & 17 & 0.12 & 140 \\
\hline ISO-1 & $102.3 \pm 15.1$ & $28.2 \pm 0.9$ & 3.6 \\
\hline ISO- $1^{d}$ & $330 \pm 25$ & $6.95 \pm 1.63$ & 47.5 \\
\hline
\end{tabular}

${ }^{a}$ Values are means \pm standard deviation (SD) of three experiments performed in triplicate. ${ }^{b}$ From ref. $25 .{ }^{c}$ IC $_{50}$ value, from ref. 24. ${ }^{d}$ From ref. 27.

1a. In the literature, 5-bromo- $N$-[4-(5,6-dimethoxyisoindolin-2yl)butyl]-2,3-dimethoxybenzamide $\left(K_{\mathrm{i}}\left(\sigma_{2}\right)=0.82 \mathrm{nM}\right)$ was found to possess ten-fold higher affinity for $\sigma_{2}$ receptors compared to 5-bromo- $N$ - $\{4$-[6,7-dimethoxy-3,4-dihydroisoquinolin2(1H)-yl]butyl\}-2,3-dimethoxybenzamide $\left(K_{\mathrm{i}}\left(\sigma_{2}\right)=8.2 \pm 1.4 \mathrm{nM}\right) .{ }^{26}$ These data indicate that the 5,6-dimethoxyisoindoline moiety is a promising $\sigma_{2}$ preferred group with less lipophilicity.

To evaluate a suitable approach for future fluorine-18 radiotracer development for imaging of $\sigma_{2}$ receptors by positron emission tomography, a fluoroalkyl group was introduced. Replacement of the 4-fluorophenyl ring at the indole $\mathrm{N}$-atom with a 2-fluoroethyl residue decreased the affinity for $\sigma_{2}$ receptors but slightly increased the subtype selectivity (2 vs. siramesine). Compounds $\mathbf{3 a}$ and $\mathbf{3 b}$ with the $\sigma_{2}$ preferred group A displayed comparable affinity for $\sigma_{2}$ receptors to ISO-1. ${ }^{27}$ However, compound $3 \mathrm{~b}$ with a 3-fluoropropyl group showed decreased selectivity in comparison to compound 3a with a 2-fluoroethyl group. Replacement of $\sigma_{2}$ preferred group A with $3 H$-spiro(2-benzofuran-1,4'-piperidinyl) moiety increased the $\sigma_{1}$ affinity significantly and thus decreased the selectivity (3c vs. 3a). Moreover, replacement of 1-(4-fluorophenyl) moiety with 1-(4-iodophenyl) group slightly decreased the affinity for $\sigma_{2}$ receptors but increased the selectivity (4 vs. 1c). Replacement of the whole indole moiety with 1-(4-fluorophenyl)carbonyl group dramatically increased the affinity for $\sigma_{1}$ receptors ( 5 vs. 1a, 5 vs. 3a, 5 vs. 3b), indicating the high importance of the indole moiety to retain the selectivity for $\sigma_{2}$ receptors.

\subsection{Antiproliferative activity}

Recently, a series of compounds with the indole moiety were reported to display antiproliferative activity in MCF7 and
MCF7/adr cells. ${ }^{25}$ In order to find new scaffolds and new $\sigma_{2}$ receptor ligands as potent antitumor agents, antiproliferative activity of compounds $\mathbf{1 a}$ and $\mathbf{1 b}$ was evaluated in MCF7 (breast cancer), DU145 (androgen-independent human prostate cancer) and C6 (rat glioma) cells using the MTT assay. Antiproliferative activity of siramesine was also determined in these cells as comparison. The effects of these compounds on cellular viability were analyzed using different concentrations between $100 \mathrm{nM}$ and $100 \mu \mathrm{M}$. The results expressed as $\mathrm{EC}_{50}$ values are shown in Table 2 . All $\mathrm{EC}_{50}$ values were found to be in the micromolar range. Compound $1 \mathrm{a}$ and siramesine showed notable antiproliferative effects in MCF7 cells with $\mathrm{EC}_{50}$ values of 20.9 and $23.6 \mu \mathrm{M}$, respectively, which are consistent with that reported in the literature (with $\mathrm{EC}_{50}$ values of 17.8 and $12.3 \mu \mathrm{M}$, respectively). ${ }^{25}$ It is interesting to note that the new compound $\mathbf{1 b}$ exhibited the highest activity in MCF7 cells. Moreover, compound $\mathbf{1 b}$ displayed notable and comparable antiproliferative effects to compound 1a and siramesine in DU145 cells. However, all of the three compounds displayed a higher $\mathrm{EC}_{50}$ value in $\mathrm{C} 6$ cells than those in the human DU145 and MCF7 tumor cells. Besides compound $\mathbf{1 a}$ and siramesine, the indole-based compound $\mathbf{1 b}$ with the 5,6-dimethoxyisoindoline moiety seems to be promising as an anti-tumor agent and warrants further evaluation.

\subsection{Cell cycle analysis}

To further examine the antitumor activity of compounds 1a and $\mathbf{1 b}$, their effects on the cell cycle progression were analyzed by flow cytometry in DU145 cells. Cell cycle phase distribution in control DU145 cells and cells treated with different concentrations of $1 \mathrm{a}, 1 \mathrm{~b}$ and siramesine at $24 \mathrm{~h}$ time point is presented in Fig. 3. The percentages of $G_{1}, S$ and $G_{2}$ phases of the untreated DU145 cells (control) are $58.2 \%$, $38.6 \%$ and $3.25 \%$, respectively. Treatment with compound $1 \mathrm{a}$ or $\mathbf{1 b}$ or siramesine increased the percentage of $\mathrm{G}_{1}$ cells in a dose-dependent manner. After treatment with $40 \mu \mathrm{M} 1 \mathrm{a}$ or $30 \mu \mathrm{M} 1 \mathrm{~b}$, the percentages of $\mathrm{G}_{1}$ cells increased to $84.1 \%$ and $80.5 \%$, respectively. At the same time, the percentages of $\mathrm{S}$ cells decreased to $15.9 \%$ and $19.3 \%$, respectively. The percentage of $\mathrm{G}_{1}$ phase cells was maintained at $75.7-77.2 \%$ after treatment with 15 to $25 \mu \mathrm{M}$ siramesine. These data suggest that compounds $\mathbf{1 a}$ and $\mathbf{1 b}$ and siramesine could induce cell cycle delay and arrest the cell cycle progression predominantly at the $\mathrm{G}_{1}$ phase in DU145 cells. It was reported that $\sigma_{2}$

Table $2 \mathrm{EC}_{50}$ values of compounds $1 \mathrm{a}$ and $1 \mathrm{~b}$ in different tumor cells ${ }^{a}$

\begin{tabular}{llll}
\hline & \multicolumn{2}{l}{$\mathrm{EC}_{50}(\mu \mathrm{M})$} & \\
\cline { 2 - 4 } Cell lines & $\mathbf{1 a}$ & $\mathbf{1 b}$ & Siramesine \\
\hline MCF7 $^{b}$ & $20.9 \pm 6.3$ & $17.0 \pm 6.5$ & $23.6 \pm 7.8$ \\
MCF7 $^{b}$ & $17.8 \pm 0.4$ & - & $12.3 \pm 0.6$ \\
DU145 & $28.8 \pm 3.9$ & $26.9 \pm 6.9$ & $13.9 \pm 0.7$ \\
C6 & $76.5 \pm 4.6$ & $44.1 \pm 9.9$ & $43.1 \pm 6.2$
\end{tabular}

${ }^{a}$ Values are means \pm standard deviation (SD) of two to three experiments performed in triplicate. ${ }^{b}$ From ref. 25. 

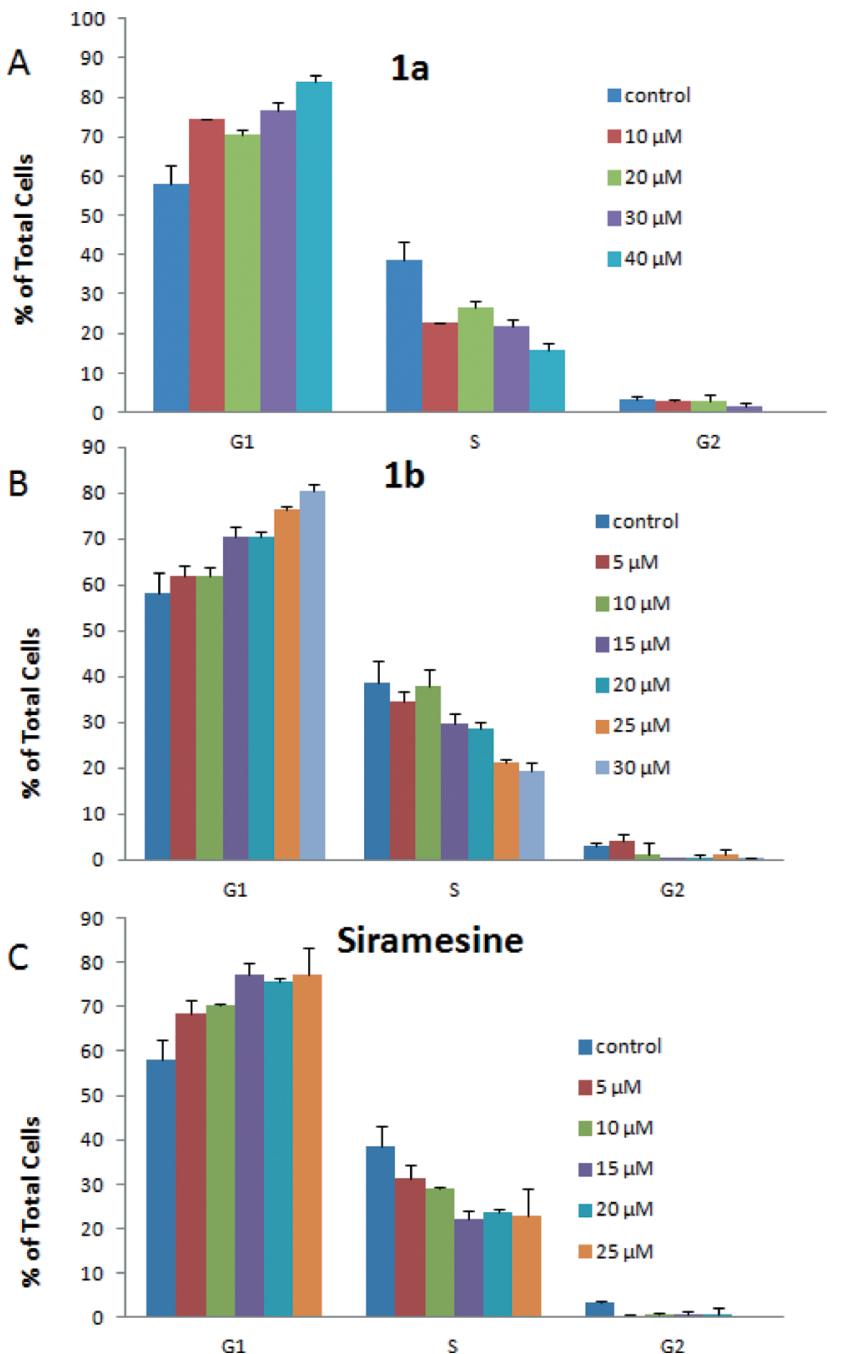

Fig. 3 Cell cycle phase distribution in control DU145 cells and cells treated with different concentrations of $1 \mathrm{a}(\mathrm{A}), 1 \mathrm{~b}(\mathrm{~B})$ and siramesine (C) at $24 \mathrm{~h}$ time point.

ligands can induce the tumor cell death by multiple signaling pathways. ${ }^{15} 10 \mu \mathrm{M}$ siramesine decreased the expression levels of cyclin D1, which are responsible for progression through the $\mathrm{G}_{1}$ phase in MDA-MB- 435 cells in a time-dependent manner. Thus, siramesine may block $\mathrm{G}_{1}$-phase progression by decreasing cyclin D1 expression. In addition, siramesine also mainly decreased cyclin B1 and pRb in MDA-MB-435 cells. The investigation of the detailed mechanism in which compounds 1a and $1 \mathbf{b}$ impair the $\mathrm{G}_{1}$ phase of the cell cycle progression in DU145 cells is in progress.

\section{Conclusion}

We have developed a series of indole-based $\sigma_{2}$ receptor ligands derived from siramesine. Structure-affinity relationship analyses indicated the high importance of the indole moiety and $\sigma_{2}$ preferred group to improve the selectivity for $\sigma_{2}$ receptors. In the MTT experiments, compound $1 \mathrm{~b}$ displayed notable and comparable antiproliferative effects to compound 1a and siramesine in DU145 cells and exhibited the highest activity in MCF7 cells. Cell cycle analysis by flow cytometry demonstrated that compounds 1a, 1b and siramesine impaired the cell cycle progression predominantly at the $\mathrm{G}_{1}$ phase in DU145 cells. The indole-based compound $1 \mathrm{~b}$ with the 5,6-dimethoxyisoindoline moiety shows potential as an antitumor agent and warrants further evaluation.

\section{Experiments}

\subsection{Chemistry}

All the chemicals or reagents were purchased from chemical suppliers and used without further purification unless otherwise noted. NMR spectra were recorded on a Varian Inova400 spectrometer or on a Bruker Avance III NMR spectrometer at $400\left({ }^{1} \mathrm{H}\right), 376\left({ }^{19} \mathrm{~F}\right)$, and $100 \mathrm{MHz}\left({ }^{13} \mathrm{C}\right)$, respectively. The chemical shifts of the spectra were reported in parts per million (ppm) with tetramethylsilane (TMS) as an internal standard, and coupling constants are reported in Hertz (Hz). MS spectra were obtained using a Xevo TQ-S spectrometer (Waters) with electrospray (ESI) as the ionization method. High-resolution mass spectrometry (HRMS) was performed on a LCT Premier XE ESI-TOF mass spectrometry instrument (Waters, USA). Chromatographic separations were carried out using Merck Silica Gel $60(63-200 \mu \mathrm{m})$. TLC detections were carried out using Merck Silica Gel $60 \mathrm{~F}_{254}$ sheets and TLCs were developed by visualization under UV light $(\lambda=254 \mathrm{~nm})$. Microanalyses were carried out using a Hekatech CHNS elemental analyser EuroEA 3000 or an Elementar 240C device (PerkinElmer). The HPLC analyses were performed using an AGILENT 1100 HPLC (Agilent Technologies, USA) equipped with a DAD detector. Analyses were carried out using a Nucleodur C18 ISIS column $(250 \times 4 \mathrm{~mm}, 5 \mu \mathrm{m}$, Macherey-Nagel, Germany) with an eluent of acetonitrile/ $\mathrm{H}_{2} \mathrm{O}(0.1 \%$ TFA $)(30: 70)$ at a flow rate of $0.5 \mathrm{~mL} \mathrm{~min}{ }^{-1}$. Cell cycle analysis was performed using a BD FACSCalibur flow cytometer (BD Biosciences, California, USA), and DNA distributions were analyzed using Modfit LT MacIntel (Verity Software House, Topsham, ME, USA).

4.1.1. tert-Butyl $4-\{4-[2-(2$-fluoroethoxy)ethoxy]phenyl\}piperazine1-carboxylate (Boc-13). Compounds $7(168 \mathrm{mg}, 0.60 \mathrm{mmol})$ and $10(190 \mathrm{mg}, 0.72 \mathrm{mmol})$ were dissolved in $\mathrm{CH}_{3} \mathrm{CN}(25 \mathrm{~mL})$, followed by addition of $\mathrm{K}_{2} \mathrm{CO}_{3}(124 \mathrm{mg}, 0.90 \mathrm{mmol})$ and $\mathrm{NaI}$ $(27 \mathrm{mg}, 0.18 \mathrm{mmol})$. The mixture was heated under reflux and stirred overnight. After cooling and filtration, the solvent was removed under reduced pressure. The residue was purified by silica gel chromatography (PE (petroleum ether): EE (ethyl acetate) $=1: 1)$ to afford Boc-13 $(203 \mathrm{mg}, 92 \%) .{ }^{1} \mathrm{H}$ NMR (400 MHz, $\left.\mathrm{CDCl}_{3}\right): \delta 6.92-6.80(\mathrm{~m}, 4 H), 4.59(\mathrm{dt}, J=47.7$, $4.2 \mathrm{~Hz}, 2 H), 4.10(\mathrm{t}, J=5.8 \mathrm{~Hz}, 2 H), 3.86(\mathrm{t}, J=5.0 \mathrm{~Hz}, 2 H), 3.82$ $(\mathrm{dt}, J=29.8,4.2 \mathrm{~Hz}, 2 H), 3.57(\mathrm{t}, J=5.0 \mathrm{~Hz}, 4 H), 3.00(\mathrm{t}, J=4.8$ $\mathrm{Hz}, 4 H), 1.48$ (s, 9H).

4.1.2. tert-Butyl 4 -(4-\{2-[2-(2-fluoroethoxy)ethoxy]ethoxy $\}$ phenyl)piperazine-1-carboxylate (Boc-14). The procedure described for the synthesis of Boc-13 was applied to compounds 7 (152 mg, $0.55 \mathrm{mmol})$ and $11(188 \mathrm{mg}, 0.61 \mathrm{mmol})$ to afford Boc-14 (171 mg, 75\%). ${ }^{1} \mathrm{H}$ NMR (400 MHz, $\left.\mathrm{CDCl}_{3}\right): \delta$ 6.91-6.80 (m, 4H), $4.57(\mathrm{dt}, J=47.7,4.2 \mathrm{~Hz}, 2 H), 4.09(\mathrm{t}, J=$ 
$4.8 \mathrm{~Hz}, 2 H), 3.84(\mathrm{t}, J=4.8 \mathrm{~Hz}, 2 H), 3.81-3.70(\mathrm{~m}, 6 H), 3.57$ $(\mathrm{t}, J=5.0 \mathrm{~Hz}, 4 H), 3.00(\mathrm{t}, J=4.8 \mathrm{~Hz}, 4 H), 1.48(\mathrm{~s}, 9 H)$.

4.1.3. tert-Butyl 4-[3-(2-fluoroethoxy)phenyl]piperazine-1carboxylate (Boc-15). The procedure described for the synthesis of Boc-13 was applied to compounds 8 (414 mg, 1.49 $\mathrm{mmol})$ and 9 (188 $\mathrm{mg}, 2.90 \mathrm{mmol})$ to afford Boc-15 $(311 \mathrm{mg}$, 64\%). ${ }^{1} \mathrm{H}$ NMR (400 MHz, $\left.\mathrm{CDCl}_{3}\right): \delta 7.18(\mathrm{t}, J=8.2 \mathrm{~Hz}, 1 H$ ), $6.57(\mathrm{~d}, J=8.2 \mathrm{~Hz}, 1 H), 6.51(\mathrm{~s}, 1 H), 6.44(\mathrm{~d}, J=8.1 \mathrm{~Hz}, 1 H)$, $4.74(\mathrm{dt}, J=47.4,4.1 \mathrm{~Hz}, 2 H), 4.20(\mathrm{dt}, J=27.9,4.1 \mathrm{~Hz}, 2 H)$, $3.57(\mathrm{t}, J=4.7 \mathrm{~Hz}, 4 H), 3.14(\mathrm{t}, J=4.4 \mathrm{~Hz}, 4 H), 1.48(\mathrm{~s}, 9 H)$.

4.1.4. General procedure for the syntheses of compounds 12, 13, 14, and 15. The Boc-protected group of compound Boc-12, Boc-13, Boc-14, or Boc-15 was cleaved using TFA in dichloromethane solution at $0{ }^{\circ} \mathrm{C}$ for $1 \mathrm{~h}$. Compounds 12-15 were obtained in nearly quantitative yields and used for the next step without further purification.

\subsection{General procedure for the syntheses of $1 \mathrm{a}-1 \mathrm{~g}$}

3-(4-Bromobutyl)-1-(4-fluorophenyl)- $1 H$-indole (6) and the respective amine (12-18) were dissolved in $\mathrm{CH}_{3} \mathrm{CN}$, followed by addition of $\mathrm{K}_{2} \mathrm{CO}_{3}$. The mixture was heated under reflux and stirred overnight. After cooling and filtration, the solvent was removed under reduced pressure. The residue was purified by silica gel chromatography ( $\mathrm{PE}: \mathrm{EE}=1: 1)$ to afford 1a-1g.

4.2.1. 2-\{4-[1-(4-Fluorophenyl)-1H-indol-3-yl]butyl\}-6,7dimethoxy-1,2,3,4-tetrahydroisoquinoline (1a). The synthesis of $1 \mathrm{a}$ was similar to that reported in the literature. ${ }^{25}$ 3-(4-Bromobutyl)-1-(4-fluorophenyl)-1 $H$-indole (18) (321 mg, 0.92 mmol), 6,7-dimethoxy-1,2,3,4-tetrahydroisoquinoline hydrochloride (5) (176 mg, $0.77 \mathrm{mmol})$ and $\mathrm{K}_{2} \mathrm{CO}_{3}(233 \mathrm{mg}$, $1.69 \mathrm{mmol})$ dissolved in $\mathrm{CH}_{3} \mathrm{CN}(25 \mathrm{~mL})$ afforded $1 \mathrm{a}(185 \mathrm{mg}$, $44 \%$ ) as light-yellow oil. ${ }^{1} \mathrm{H}$ NMR (400 $\left.\mathrm{MHz} \mathrm{CDCl}_{3}\right): \delta 7.88-$ $7.66(\mathrm{~m}, 1 H), 7.50-7.40(\mathrm{~m}, 3 H), 7.28-7.13(\mathrm{~m}, 4 H), 7.10$ (s, $1 H), 6.60(\mathrm{~s}, 1 H), 6.52(\mathrm{~s}, 1 H), 3.85(\mathrm{~s}, 3 H), 3.84(\mathrm{~s}, 3 H), 3.57$ $(\mathrm{s}, 2 H), 2.90-2.80(\mathrm{~m}, 4 H), 2.72(\mathrm{t}, J=5.9 \mathrm{~Hz}, 2 H), 2.62-2.54$ (m, 2H), 1.89-1.82 (m, 2H), 1.82-1.70 (m, 2H); ${ }^{13} \mathrm{C}$ NMR (100 $\left.\mathrm{MHz}, \mathrm{CDCl}_{3}\right): \delta 160.7,147.5,147.2,136.3,136.0,128.9,126.1$, 125.8, 125.7, 125.1, 122.4 (2C), 119.7, 119.3, 117.7, 116.3 (2C), 111.3, 110.1, 109.5, 58.1, 55.9 (2C), 55.7, 51.0, 28.5, 27.9, 27.1, 24.9; ${ }^{19} \mathrm{~F} \mathrm{NMR} \mathrm{(376} \mathrm{MHz,} \mathrm{CDCl}_{3}$ ): $\delta-116.0$; $\mathrm{MS}\left(\mathrm{ESI}^{+}\right): \mathrm{m} / z=$ calcd. for $\mathrm{C}_{29} \mathrm{H}_{31} \mathrm{FN}_{2} \mathrm{O}_{2}[\mathrm{M}+\mathrm{H}]^{+}$459.2, found 459.0; HRMS (EI): $m / z$ calcd. for $\mathrm{C}_{29} \mathrm{H}_{31} \mathrm{FN}_{2} \mathrm{O}_{2}[\mathrm{M}+\mathrm{H}]^{+} 459.2448$, found 459.2441. Anal. calcd. for $\mathrm{C}_{29} \mathrm{H}_{31} \mathrm{FN}_{2} \mathrm{O}_{2} \cdot 3 / 4 \mathrm{H}_{2} \mathrm{O}$ (472.08): $\mathrm{C}$ 73.78, H 6.94, N 5.93; found: C 73.52, H 6.83, N 5.74.

4.2.2. 3-[4-(5,6-Dimethoxyisoindolin-2-yl)butyl]-1-(4fluorophenyl)-1H-indole (1b). Compounds 6 (233 mg, 0.67 $\mathrm{mmol}$ ) and 17 (119 mg, $0.67 \mathrm{mmol}$ ) and $\mathrm{K}_{2} \mathrm{CO}_{3}$ (144 mg, 1.04 $\mathrm{mmol}$ ) in $\mathrm{CH}_{3} \mathrm{CN}(25 \mathrm{~mL})$ afforded $1 \mathrm{~b}$ as brown solid (156 $\mathrm{mg}, 52 \%) .{ }^{1} \mathrm{H}$ NMR (400 MHz, $\left.\mathrm{CDCl}_{3}\right): \delta 7.65-7.69(\mathrm{~m}, 1 H)$, 7.49-7.41 (m, 3H), 7.25-7.15 (m, 4H), $7.11(\mathrm{~s}, 1 H), 6.74$ (s, 2H), $3.91(\mathrm{~s}, 4 H), 3.86(\mathrm{~s}, 6 H), 2.87(\mathrm{t}, J=7.4 \mathrm{~Hz}, 2 H), 2.79$ $(\mathrm{t}, J=7.4 \mathrm{~Hz}, 2 H), 1.92-1.83(\mathrm{~m}, 2 H), 1.78-1.67(\mathrm{~m}, 2 H) ;{ }^{13} \mathrm{C}$ NMR (100 MHz, $\left.\mathrm{CDCl}_{3}\right): \delta$ 160.7, 148.4 (2C), 136.3, 136.0, 131.6 (2C), 128.9, 125.8, 125.1, 122.4 (2C), 119.7, 119.3, 117.8, 116.3 (2C), 110.1, 106.8 (2C), 59.2 (2C), 56.1 (2C), 28.9, 27.8
(2C), 24.9; ${ }^{19} \mathrm{~F}$ NMR (376 $\left.\mathrm{MHz}, \mathrm{CDCl}_{3}\right): \delta-116.0 ; \mathrm{MS}\left(\mathrm{ESI}^{+}\right)$: $m / z=$ calcd. for $\mathrm{C}_{28} \mathrm{H}_{29} \mathrm{FN}_{2} \mathrm{O}_{2}[\mathrm{M}+\mathrm{H}]^{+}$445.2, found 445.2; HRMS (EI): $m / z$ calcd. for $\mathrm{C}_{28} \mathrm{H}_{29} \mathrm{FN}_{2} \mathrm{O}_{2}[\mathrm{M}+\mathrm{H}]^{+}$445.2291, found 445.2296. Anal. calcd. for $\mathrm{C}_{28} \mathrm{H}_{29} \mathrm{FN}_{2} \mathrm{O}_{2}$ (444.54): C 75.65, H 6.58, N 6.30; found: C 75.14, H 6.62, N 6.30.

4.2.3. $\quad 1-\{4-[1-(4-F l u o r o p h e n y l)-1 H$-indol-3-yl] butyl $\}-4-$ phenylpiperdine-4-carbonitrile (1c). Compounds 6 (121 mg, $0.35 \mathrm{mmol}$ ) and 18 (89 mg, $0.48 \mathrm{mmol})$ and $\mathrm{K}_{2} \mathrm{CO}_{3}$ (483 mg, $3.5 \mathrm{mmol})$ in $\mathrm{CH}_{3} \mathrm{CN}(25 \mathrm{~mL})$ afforded 1c as light-yellow oil (66 mg, 42\%). ${ }^{1} \mathrm{H}$ NMR (400 MHz, MeOD) $\delta 7.52$ (d, $J=7.7$ $\mathrm{Hz}, 1 H), 7.44-7.36(\mathrm{~m}, 4 H), 7.36-7.27$ (m 3H), 7.25-7.20 (m, 1H), 7.19-7.10 (m, 3H), 7.09-7.04 (m, 1H), 7.03-6.98 (m, 1H), $2.94(\mathrm{~d}, J=12.1 \mathrm{~Hz}, 2 H), 2.75(\mathrm{t}, J=7.3 \mathrm{~Hz}, 2 H), 2.39(\mathrm{t}, J=7.7 \mathrm{~Hz}$, $2 H)$, 2.36-2.26 (m, 2H), 1.98 (t, $J=7.7 \mathrm{~Hz}, 4 H), 1.75-1.65(\mathrm{~m}, 2 H)$, 1.61-1.51 (m, 2H); ${ }^{13} \mathrm{C}$ NMR (100 MHz, $\left.\mathrm{CDCl}_{3}\right): \delta$ 137.0, 136.4, 135.8, 129.5, 129.1, 128.5 (2C), 126.0, 125.9, 125.6 (2C), 122.7, 120.4 (2C), 120.1, 119.1. 116.6, 116.3 (2C), 110.4, 57.7, 50.4 (2C), 41.9, 33.5 (2C), 27.3, 24.5, 23.6; $\mathrm{MS}\left(\mathrm{ESI}^{+}\right): \mathrm{m} / \mathrm{z}=$ calcd. for $\mathrm{C}_{30} \mathrm{H}_{30} \mathrm{FN}_{3}[\mathrm{M}+\mathrm{H}]^{+}$452.3, found 452.7; HRMS (EI): $\mathrm{m} / z$ calcd. for $\mathrm{C}_{30} \mathrm{H}_{30} \mathrm{FN}_{3}[\mathrm{M}+\mathrm{H}]^{+}$452.2502, found 452.2505. Anal. calcd. for $\mathrm{C}_{30} \mathrm{H}_{30} \mathrm{FN}_{3} \cdot \mathrm{HCl} \cdot 1 / 4 \mathrm{H}_{2} \mathrm{O}$ : $\mathrm{C}$ 73.16, $\mathrm{N} 8.53, \mathrm{H} 6.45$; found: C 73.19, N 8.48, H 6.69.

4.2.4. $3-(4-\{4-[4-(2-F l u o r o e t h o x y) p h e n y l]$ piperazin-1-yl $\}$ butyl)1-(4-fluorophenyl)-1H-indole (1d). Compounds $6(180 \mathrm{mg}$, $0.52 \mathrm{mmol}$ ) and $12(132 \mathrm{mg}, 0.59 \mathrm{mmol})$ and $\mathrm{K}_{2} \mathrm{CO}_{3}(680 \mathrm{mg}$, $4.92 \mathrm{mmol}$ ) in $\mathrm{CH}_{3} \mathrm{CN}(25 \mathrm{~mL})$ afforded $1 \mathrm{~d}$ as white solid (210 mg, 83\%). ${ }^{1} \mathrm{H}$ NMR (400 $\left.\mathrm{MHz}, \mathrm{CDCl}_{3}\right): \delta 7.65$ (d, $J=$ $7.6 \mathrm{~Hz}, 1 H), 7.48-7.40(\mathrm{~m}, 3 H), 7.24-7.12(\mathrm{~m}, 4 H), 7.08(\mathrm{~s}, 1 H)$, 6.93-6.83 (m, 4H), $4.71(\mathrm{dt}, J=47.4,4.1 \mathrm{~Hz}, 2 H), 4.16(\mathrm{dt}, J=$ 27.9, $4.2 \mathrm{~Hz}, 2 H), 3.10(\mathrm{t}, J=4.8 \mathrm{~Hz}, 4 H), 2.84(\mathrm{t}, J=7.4 \mathrm{~Hz}, 2 H)$, $2.61(\mathrm{t}, J=4.7 \mathrm{~Hz}, 4 H), 2.46(\mathrm{t}, J=7.6 \mathrm{~Hz}, 2 H), 1.86-1.75$ $(\mathrm{m}, 2 H), 1.72-1.61(\mathrm{~m}, 2 H) ;{ }^{13} \mathrm{C}$ NMR (100 $\left.\mathrm{MHz}, \mathrm{CDCl}_{3}\right): \delta$ $160.8,152.5,146.3,136.4,136.1,128.9,125.9$ (2C), 125.1, 122.5, 119.8, 119.4, 118.0 (2C), 117.8, 116.4 (2C), 115.5 (2C), 110.2, 82.1, 67.7, 58.6 (2C), 53.4, 50.4 (2C), 28.0, 26.9, 25.0; MS (ESI $\left.{ }^{+}\right)$: $\mathrm{m} / \mathrm{z}$ = calcd. for $\mathrm{C}_{30} \mathrm{H}_{33} \mathrm{~F}_{2} \mathrm{~N}_{3} \mathrm{O}[\mathrm{M}+\mathrm{H}]^{+} 490.3$, found 490.6. Anal. calcd. for $\mathrm{C}_{30} \mathrm{H}_{33} \mathrm{~F}_{2} \mathrm{~N}_{3} \mathrm{O}$ (489.60): $\mathrm{C} 73.60, \mathrm{H}$ 6.79, $\mathrm{N}$ 8.58; found: C 73.99, $\mathrm{H} 7.12, \mathrm{~N} 8.26$.

4.2.5 3-[4-(4-\{4-[2-(2-Fluoroethoxy)ethoxy]phenyl $\}$ piperazin1-yl)butyl]-1-(4-fluorophenyl)-1H-indole (1e). Compounds 6 (488 $\mathrm{mg}, 1.41 \mathrm{mmol}$ ) and $13\left(138 \mathrm{mg}, 0.51 \mathrm{mmol}\right.$ ) and $\mathrm{K}_{2} \mathrm{CO}_{3}$ (84 mg, $0.61 \mathrm{mmol}$ ) in $\mathrm{CH}_{3} \mathrm{CN}(25 \mathrm{~mL})$ afforded 1e as lightyellow oil (43 mg, 16\%). ${ }^{1} \mathrm{H}$ NMR (400 $\mathrm{MHz} \mathrm{CDCl}_{3}$ ): $\delta 7.65$ (t, $J=7.6 \mathrm{~Hz}, 1 H), 7.50-7.40(\mathrm{~m}, 3 H), 7.24-7.13(\mathrm{~m}, 4 H), 7.08$ $(\mathrm{s}, 1 H), 6.91-6.82(\mathrm{~m}, 4 H), 4.58(\mathrm{dt}, J=47.7,4.1 \mathrm{~Hz}, 2 H), 4.09$ $(\mathrm{t}, J=4.8 \mathrm{~Hz}, 2 H), 3.89-3.75(\mathrm{~m}, 4 H), 3.10(\mathrm{t}, J=4.7 \mathrm{~Hz}, 4 H)$, $2.84(\mathrm{t}, J=7.4 \mathrm{~Hz}, 2 H), 2.62(\mathrm{t}, J=4.5 \mathrm{~Hz}, 4 H), 2.46(\mathrm{t}, J=$ $7.6 \mathrm{~Hz}, 2 H), 1.85-1.74(\mathrm{~m}, 2 H), 1.72-1.62(\mathrm{~m}, 2 H) ;{ }^{13} \mathrm{C} \mathrm{NMR}$ $\left(100 \mathrm{MHz}, \mathrm{CDCl}_{3}\right): \delta 160.8,152.8,146.0,136.3,136.0,128.9$, 125.8, 125.8 (2C), 125.1, 122.5, 119.6 (2C), 118.0 (2C), 117.8, 116.4, 115.4 (2C), 110.2, 83.2, 70.6, 70.1, 68.0, 58.6 (2C), 53.4, 50.5 (2C), 28.0, 26.8, 25.0. HRMS (EI): $\mathrm{m} / \mathrm{z}$ calcd. for $\mathrm{C}_{32} \mathrm{H}_{37} \mathrm{~F}_{2} \mathrm{~N}_{3} \mathrm{O}_{2}[\mathrm{M}+\mathrm{H}]^{+}$534.2932, found 534.2916.

4.2.6. $3-\{4-[4-(4-\{2-[2-(2-$ Fluoroethoxy $)$ ethoxy]ethoxy $\}-$ phenyl)piperazin-1-yl]butyl $\}$-1-(4-fluorophenyl)-1H-indole (1f). Compounds 6 (142 mg, $0.41 \mathrm{mmol})$ and 14 (129 mg, 0.41 
$\mathrm{mmol})$ and $\mathrm{K}_{2} \mathrm{CO}_{3}(70 \mathrm{mg}, 0.51 \mathrm{mmol})$ in $\mathrm{CH}_{3} \mathrm{CN}(25 \mathrm{~mL})$ afforded 1f (68 mg, 29\%). ${ }^{1} \mathrm{H}$ NMR (400 $\left.\mathrm{MHz}, \mathrm{CDCl}_{3}\right): \delta 7.65$ $(\mathrm{d}, J=7.6 \mathrm{~Hz}, 1 H), 7.48-7.40(\mathrm{~m}, 3 H), 7.24-7.14(\mathrm{~m}, 4 H), 7.08$ (s, 1H), 6.91-6.82 (m, 4H), $4.56(\mathrm{dt}, J=47.7,4.1 \mathrm{~Hz}, 2 H), 4.08$ $(\mathrm{t}, J=4.8 \mathrm{~Hz}, 2 H), 3.83(\mathrm{t}, J=4.8 \mathrm{~Hz}, 2 H), 3.80-3.68(\mathrm{~m}, 6 H)$, $3.10(\mathrm{t}, J=4.7 \mathrm{~Hz}, 4 H), 2.84(\mathrm{t}, J=7.4 \mathrm{~Hz}, 2 H), 2.61(\mathrm{t}, J=4.8$ $\mathrm{Hz}, 4 H), 2.46(\mathrm{t}, J=7.6 \mathrm{~Hz}, 2 H), 1.85-1.75(\mathrm{~m}, 2 H), 1.74-1.63$ $(\mathrm{m}, 2 H) ;{ }^{13} \mathrm{C}$ NMR $\left(100 \mathrm{MHz}, \mathrm{CDCl}_{3}\right): \delta 160.7,152.9,145.9$, $136.3,136.0,128.9,125.8,125.7,125.1,122.4,119.5$ (2C), 118.0 (2C), 117.7, 116.3 (2C), 115.3 (2C), 110.1, 83.1, 70.8, 70.5, 70.3, 69.9, 67.8, 58.6, 53.4 (2C), 50.5 (2C), 27.9, 26.8, 24.9; $\mathrm{MS}\left(\mathrm{ESI}^{+}\right): m / z=$ calcd. for $\mathrm{C}_{34} \mathrm{H}_{41} \mathrm{~F}_{2} \mathrm{~N}_{3} \mathrm{O}_{3}[\mathrm{M}+\mathrm{H}]^{+}$577.3, found 577.4. Anal. calcd. for $\mathrm{C}_{34} \mathrm{H}_{41} \mathrm{~F}_{2} \mathrm{~N}_{3} \mathrm{O}_{3} \cdot 2 \mathrm{HCl} \cdot \mathrm{H}_{2} \mathrm{O}$ (668.64): C 61.07, H 6.78, N 6.28; found: C 61.47, H 6.80, N 6.38 .

4.2.7. 3-(4-\{4-[3-(2-Fluoroethoxy)phenyl]piperazin-1-yl $\} b u t y l)-$ 1-(4-fluorophenyl)-1H-indole (1g). Compounds 6 (259 mg, $0.75 \mathrm{mmol}$ ) and 15 (168 mg, $0.75 \mathrm{mmol})$ and $\mathrm{K}_{2} \mathrm{CO}_{3}(132 \mathrm{mg}$, $0.97 \mathrm{mmol}$ ) in $\mathrm{CH}_{3} \mathrm{CN}(25 \mathrm{~mL}$ ) afforded $1 \mathrm{~g}$ as light-yellow oil (130 mg, 35\%). ${ }^{1} \mathrm{H}$ NMR (400 $\mathrm{MHz}, \mathrm{CDCl}_{3}$ ): $\delta$ 7.68-7.61 $(\mathrm{m}, 1 H), 7.47-7.39(\mathrm{~m}, 3 H), 7.22-7.11(\mathrm{~m}, 5 H), 7.07(\mathrm{~s}, 1 H)$, 6.59-6.53 (m, 1H), $6.49(\mathrm{t}, J=2.3 \mathrm{~Hz}, 1 \mathrm{H}), 6.44-6.36(\mathrm{~m}, 1 H)$, $4.71(\mathrm{dt}, J=47.1,4.2 \mathrm{~Hz}, 2 H), 4.17$ (dt, $J=27.8,4.2 \mathrm{~Hz}, 2 H$ ), $3.18(\mathrm{t}, J=5.2 \mathrm{~Hz}, 4 H), 2.83(\mathrm{t}, J=7.4 \mathrm{~Hz}, 2 H), 2.57(\mathrm{t}, J=$ $5.0 \mathrm{~Hz}, 4 H), 2.43(\mathrm{t}, J=7.6 \mathrm{~Hz}, 2 H), 1.87-1.71(\mathrm{~m}, 2 H), 1.73-$ $1.60(\mathrm{~m}, 2 H) ;{ }^{13} \mathrm{C}$ NMR (100 MHz, $\left.\mathrm{CDCl}_{3}\right): \delta 160.7,159.4,152.7$, 136.3, 136.0, 129.7, 128.8, 125.8 (2C), 125.1, 122.4, 119.8, 119.3, 117.7, 116.3 (2C), 110.1, 109.3, 104.6, 103.2, 82.0, 67.0, 58.6, 53.2 (2C), 48.9 (2C), 27.9, 26.8, 24.9; ${ }^{19} \mathrm{~F}$ NMR (376 MHz, $\left.\mathrm{CDCl}_{3}\right): \quad \delta$-120.7, -228.6; $\mathrm{MS}\left(\mathrm{ESI}^{+}\right): \mathrm{m} / \mathrm{z}=$ calcd. for $\mathrm{C}_{30} \mathrm{H}_{33} \mathrm{~F}_{2} \mathrm{~N}_{3} \mathrm{O}[\mathrm{M}+\mathrm{H}]^{+}$490.3, found 490.5; HRMS (EI): $\mathrm{m} / \mathrm{z}$ calcd. for $\mathrm{C}_{30} \mathrm{H}_{33} \mathrm{~F}_{2} \mathrm{~N}_{3} \mathrm{O}[\mathrm{M}+\mathrm{H}]^{+}$490.2670, found 490.2673. Anal. calcd. for $\mathrm{C}_{30} \mathrm{H}_{33} \mathrm{~F}_{2} \mathrm{~N}_{3} \mathrm{O} \cdot \mathrm{H}_{2} \mathrm{O}$ (507.61): $\mathrm{C}$ 70.98, $\mathrm{H}$ 6.95, N 8.28; found: C 71.18, $\mathrm{H} 6.87, \mathrm{~N} 8.01$.

4.2.8. $3-\{4-[($ tert-Butyldimethylsilyl)oxy]butyl $\}-1 H$-indole (20). To a solution of $19(2.10 \mathrm{~g}, 11.1 \mathrm{mmol})$ in $\mathrm{CH}_{2} \mathrm{Cl}_{2}(40$ $\mathrm{mL}$ ), TBDMSCl (2.06 g, $13.7 \mathrm{mmol})$ and imidazole (1.43 g, $21.0 \mathrm{mmol}$ ) were added. The mixture was stirred at room temperature for $2 \mathrm{~h}$. After filtration, the solvent was removed under reduced pressure. The residue was purified by silica gel chromatography ( $\mathrm{PE}: \mathrm{EE}=1: 5)$ to afford $20(2.80 \mathrm{~g}, 84 \%)$. ${ }^{1} \mathrm{H}$ NMR (400 MHz, $\mathrm{CDCl}_{3}$ ): $\delta 7.87(\mathrm{~s}, 1 \mathrm{H}), 7.58(\mathrm{~d}, J=7.9 \mathrm{~Hz}$, $1 H), 7.32(\mathrm{~d}, J=8.1 \mathrm{~Hz}, 1 H), 7.20-7.13(\mathrm{~m}, 1 H), 7.12-7.04(\mathrm{~m}, 1 H)$, $6.95(\mathrm{~s}, 1 H), 3.63(\mathrm{t}, J=6.5 \mathrm{~Hz}, 2 H), 2.75(\mathrm{t}, J=7.5 \mathrm{~Hz}, 2 H)$, 1.80-1.68 (m, 2H), 1.65-1.58 (m, 2H), $0.87(\mathrm{~s}, 9 H)$.

4.2.9. 2-(3-\{4-[(tert-Butyldimethylsilyl)oxy]butyl $\}-1 H$-indol-1yl)ethanol (21). To a solution of compound 20 (1.88 g, 6.19 $\mathrm{mmol}$ ) in DMF, 2-bromoethanol (1.23 g, $9.92 \mathrm{mmol})$ and $\mathrm{NaH}$ (240 mg, $10.0 \mathrm{mmol}$ ) were added. The mixture was stirred at $110{ }^{\circ} \mathrm{C}$ overnight. After cooling, the crude product was extracted with ethyl acetate, dried with anhydrous $\mathrm{MgSO}_{4}$, and purified by silica gel column chromatography (PE: $\mathrm{EE}=5: 1)$ to afford 21 (805 mg, 37\%). ${ }^{1} \mathrm{H}$ NMR (400 $\left.\mathrm{MHz}, \mathrm{CDCl}_{3}\right): \delta 7.57(\mathrm{~d}, J=7.9 \mathrm{~Hz}, 1 H), 7.30(\mathrm{~d}, J=8.2 \mathrm{~Hz}$, $1 H), 7.20-7.15(\mathrm{~m}, 1 H), 7.10-7.05(\mathrm{~m}, 1 H), 6.91(\mathrm{~s}, 1 H), 4.21$ $(\mathrm{t}, J=5.3 \mathrm{~Hz}, 2 H), 3.92(\mathrm{t}, J=5.3 \mathrm{~Hz}, 2 H), 3.62(\mathrm{t}, J=6.4 \mathrm{~Hz}$,
$2 H), 2.73(\mathrm{t}, J=7.5 \mathrm{~Hz}, 2 H), 1.79-1.65(\mathrm{~m}, 2 H), 1.65-1.53$ $(\mathrm{m}, 2 H), 0.87(\mathrm{~s}, 9 H)$.

4.2.10. $2-(3-\{4-[($ tert-Butyldimethylsilyl)oxy] butyl $\}-1 H$-indol1-yl)ethyl 4-methylbenzenesulfonate (22). Compound 21 (805 $\mathrm{mg}, 2.32 \mathrm{mmol}$ ), TsCl (661 mg, $3.48 \mathrm{mmol}$ ), DIPEA (450 mg, $3.48 \mathrm{mmol}$ ), and DMAP (425 $\mathrm{mg}, 3.48 \mathrm{mmol}$ ) were dissolved in $30 \mathrm{~mL}$ of THF. The mixture was stirred at room temperature for $2 \mathrm{~h}$. After the solvent was removed under reduced pressure, the crude product was extracted with $\mathrm{CH}_{2} \mathrm{Cl}_{2}$. The organic layer was dried over $\mathrm{MgSO}_{4}$, filtered, and concentrated under vacuum. The residue was purified by silica gel chromatography (PE: $\mathrm{EE}=10: 1)$ to afford $22(208 \mathrm{mg}, 18 \%)$. ${ }^{1} \mathrm{H}$ NMR (400 MHz, $\left.\mathrm{CDCl}_{3}\right): \delta 7.63-7.56(\mathrm{~m}, 1 H), 7.49(\mathrm{~d}, J=$ $8.3 \mathrm{~Hz}, 2 H), 7.17-7.04(\mathrm{~m}, 5 H), 6.80(\mathrm{~s}, 1 H), 4.36-4.24$ $(\mathrm{m}, 4 H), 3.72(\mathrm{t}, J=6.3 \mathrm{~Hz}, 2 H), 2.75(\mathrm{t}, J=7.5 \mathrm{~Hz}, 2 H), 2.36$ (s, 3H), 1.86-1.73 (m, 2H), 1.73-1.64 (m, 2H), $0.97(\mathrm{~s}, 9 H)$.

4.2.11. 4-[1-(2-Fluoroethyl)-1H-indol-3-yl] butan-1-ol (23). TBAF (345 mg, 1.32mmol) and $22(265 \mathrm{mg}, 0.53 \mathrm{mmol})$ were added into THF $(20 \mathrm{~mL})$. The mixture was stirred at room temperature overnight. After the solvent was removed under reduced pressure, the crude product was extracted with $\mathrm{CH}_{2} \mathrm{Cl}_{2}$. The organic layer was dried over $\mathrm{MgSO}_{4}$, filtered, and concentrated under vacuum. The residue was purified by silica gel chromatography ( $\mathrm{PE}: \mathrm{EE}=3: 1)$ to afford $23(69 \mathrm{mg}$, 56\%). ${ }^{1} \mathrm{H}$ NMR (400 MHz, $\left.\mathrm{CDCl}_{3}\right): \delta 7.63(\mathrm{~d}, J=7.9 \mathrm{~Hz}, 1 H)$, $7.30(\mathrm{~d}, J=8.1 \mathrm{~Hz}, 1 H), 7.43-7.21(\mathrm{~m}, 2 H), 7.17-7.10(\mathrm{~m}, 1 H)$, $6.95(\mathrm{~s}, 1 H), 4.69(\mathrm{dt}, J=47.0,5.0 \mathrm{~Hz}, 2 H), 4.35(\mathrm{dt}, J=25.7$, $4.9 \mathrm{~Hz}, 2 H), 3.68(\mathrm{t}, J=6.5 \mathrm{~Hz}, 2 H), 2.80(\mathrm{t}, J=7.4 \mathrm{~Hz}, 2 H)$, 1.87-1.75 (m, 2H), 1.75-1.63 (m, 2H).

4.2.12. 4-[1-(2-Fluoroethyl)-1H-indol-3-yl]butyl 4-methylbenzenesulfonate (24). To a solution of $23(120 \mathrm{mg}, 0.51$ $\mathrm{mmol}$ ) in THF (20 mL), TsCl (116 mg, $0.61 \mathrm{mmol})$, DIPEA (129 mg, $1.00 \mathrm{mmol}$ ), and DMAP (122 mg, $1.00 \mathrm{mmol}$ ) were added. The mixture was stirred at room temperature for $2 \mathrm{~h}$. After the solvent was removed under reduced pressure, the crude product was extracted with $\mathrm{CH}_{2} \mathrm{Cl}_{2}$. The organic layer was dried over $\mathrm{MgSO}_{4}$, filtered, and concentrated under vacuum. The residue was purified by silica gel chromatography (PE: $\mathrm{EE}=5: 1)$ to afford $24(88 \mathrm{mg}, 44 \%) .{ }^{1} \mathrm{H}$ NMR $(400 \mathrm{MHz}$, $\left.\mathrm{CDCl}_{3}\right): \delta 7.76(\mathrm{~d}, J=8.3 \mathrm{~Hz}, 2 H), 7.50(\mathrm{~d}, J=7.9 \mathrm{~Hz}, 1 H)$, 7.32-7.16 (m, 4H), 7.11-7.05 (m, 1H), $6.86(\mathrm{~s}, 1 H), 4.66(\mathrm{dt}, J=$ $47.0,5.0 \mathrm{~Hz}, 2 H), 4.32(\mathrm{dt}, J=25.8,5.0 \mathrm{~Hz}, 2 H), 4.07-3.99$ $(\mathrm{m}, 2 H), 2.68(\mathrm{t}, J=6.7 \mathrm{~Hz}, 2 H), 2.40(\mathrm{~s}, 3 H), 1.75-1.68(\mathrm{~m}, 4 H)$.

4.2.13. $\quad 1^{\prime}-\{4-[1-(2-F l u o r o e t h y l)-1 H$-indol-3-yl]butyl $\}-3 H$ spiro[isobenzofuran-1,4'-piperidine] (2). To a solution of 24 ( $88 \mathrm{mg}, 0.23 \mathrm{mmol}$ ) in $20 \mathrm{~mL}$ of $\mathrm{CH}_{3} \mathrm{CN}, 3 \mathrm{H}$-spiro[isobenzofuran-1,4'-piperidine] (25) (32 $\mathrm{mg}, 0.17 \mathrm{mmol}$ ) and $\mathrm{K}_{2} \mathrm{CO}_{3}(32$ $\mathrm{mg}, 0.23 \mathrm{mmol}$ ) were added. The mixture was stirred at $80{ }^{\circ} \mathrm{C}$ for $4 \mathrm{~h}$. After the solvent was removed under reduced pressure, the residue was purified by silica gel chromatography (PE: $\mathrm{EE}=1: 1)$ to afford $2(26 \mathrm{mg}, 38 \%) .{ }^{1} \mathrm{H} \mathrm{NMR}(400 \mathrm{MHz}$, $\left.\mathrm{CDCl}_{3}\right): \delta 7.62(\mathrm{~d}, J=7.8 \mathrm{~Hz}, 1 H), 7.31-7.25(\mathrm{~m}, 3 H), 7.24-$ $7.20(\mathrm{~m}, 2 H), 7.18-7.09(\mathrm{~m}, 2 H), 6.96(\mathrm{~s}, 1 H), 5.08(\mathrm{~s}, 2 H)$, $4.70(\mathrm{dt}, J=47.0,5.0 \mathrm{~Hz}, 2 H), 4.36(\mathrm{dt}, J=25.5,5.0 \mathrm{~Hz}, 2 H)$, $2.90(\mathrm{~d}, J=11.2 \mathrm{~Hz}, 2 H), 2.80(\mathrm{t}, J=7.3 \mathrm{~Hz}, 2 H), 2.49(\mathrm{t}, J=$ $10.0 \mathrm{~Hz}, 2 H), 2.41(\mathrm{t}, J=11.1 \mathrm{~Hz}, 2 H), 2.07-1.97(\mathrm{~m}, 2 H)$, 
1.84-1.63 (m, 6H); ${ }^{13} \mathrm{C}$ NMR (100 $\left.\mathrm{MHz}, \mathrm{CDCl}_{3}\right): \delta$ 145.9, 139.1, 136.6, 128.5, 127.8, 127.6, 125.4, 121.9, 121.2, 121.1, 119.5, 119.1, 116.3, 109.1, 84.2, 81.8, 71.0, 59.1, 50.5 (2C), 46.5, 36.8 (2C), 28.5, 27.2, 25.2; ${ }^{19} \mathrm{~F}$ NMR (376 $\mathrm{MHz}, \mathrm{CDCl}_{3}$ ): $\delta$-219.8; MS $\left(\mathrm{ESI}^{+}\right): \mathrm{m} / z=$ calcd. for $\mathrm{C}_{26} \mathrm{H}_{31} \mathrm{FN}_{2} \mathrm{O}[\mathrm{M}+\mathrm{H}]^{+}$ 407.2, found 407.2; HRMS (EI): $\mathrm{m} / z$ calcd. for $\mathrm{C}_{26} \mathrm{H}_{31} \mathrm{FN}_{2} \mathrm{O}$ $[\mathrm{M}+\mathrm{H}]^{+}$407.2499, found 407.2492; purity (HPLC): 95\%.

4.2.14. 2-(1H-Indol-3-yl)ethanol (28). Under ice bath and argon atmosphere, a solution of $26(1.00 \mathrm{~g}, 5.71 \mathrm{mmol})$ in THF (60 mL) was added to a solution of $\mathrm{LiAlH}_{4}(642 \mathrm{mg}, 17.1$ $\mathrm{mmol})$ in THF $(40 \mathrm{~mL})$. The mixture was stirred for $4 \mathrm{~h}$ at room temperature, followed by addition of ethanol until no $\mathrm{H}_{2}$ was formed. Then $4 \mathrm{M}$ hydrochloric acid was added to adjust the $\mathrm{pH}$ to 5 . After filtration, the solution was concentrated under reduced pressure. The crude product was extracted with ethyl acetate, dried with anhydrous $\mathrm{MgSO}_{4}$, and purified by silica gel column chromatography (PE: EE = $5: 1)$ to afford alcohol 28 (795 mg, 86\%). ${ }^{1} \mathrm{H}$ NMR (400 MHz, $\left.\mathrm{CDCl}_{3}\right): \delta 8.02(\mathrm{~s}, 1 \mathrm{H}), 7.60(\mathrm{~d}, J=7.8 \mathrm{~Hz}, 1 H), 7.35(\mathrm{~d}, J=8.1$ $\mathrm{Hz}, 1 H), 7.21-7.16(\mathrm{~m}, 1 H), 7.13-7.09(\mathrm{~m}, 1 H), 7.06$ (d, $J=2.1$ $\mathrm{Hz}, 1 H), 3.89(\mathrm{t}, J=6.3 \mathrm{~Hz}, 2 H), 3.02(\mathrm{t}, J=6.3 \mathrm{~Hz}, 2 H)$.

4.2.15. 3-(1H-Indol-3-yl)propan-1-ol (29). The procedure described for the synthesis of 28 was applied to $27(3.00 \mathrm{~g}$, $15.8 \mathrm{mmol})$ and $\mathrm{LiAlH}_{4}(2.93 \mathrm{~g}, 77.2 \mathrm{mmol})$ to afford alcohol 29 (2.18 g, 79\%). ${ }^{1} \mathrm{H}$ NMR (400 MHz, $\mathrm{CDCl}_{3}$ ): $\delta 7.93$ (s, 1H), 7.65-7.55 (m, 1H), 7.37-7.30 (m, 1H), 7.23 (s, 1H), 7.19-7.14 $(\mathrm{m}, 1 H), 7.12-7.07(\mathrm{~m}, J=8.0,1 H), 6.97(\mathrm{~s}, 1 H), 3.71(\mathrm{t}, J=6.4$ $\mathrm{Hz}, 2 H), 2.90-2.78(\mathrm{~m}, 2 H), 2.04-1.93(\mathrm{~m}, 2 H)$.

4.2.16. 2-[1-(4-Bromobutyl)-1H-indol-3-yl]ethanol (30). Under ice bath and argon atmosphere, alcohol $28(220 \mathrm{mg}$, $1.37 \mathrm{mmol}$ ), 1,4-dibromobutane (875 mg, $4.11 \mathrm{mmol}$ ), and $\mathrm{NaH}$ (98 mg, $4.11 \mathrm{mmol}$ ) were added into DMF (30 mL). The mixture was stirred at $110{ }^{\circ} \mathrm{C}$ overnight. After cooling and filtration, the crude product was extracted with ethyl acetate, dried with anhydrous $\mathrm{MgSO}_{4}$, and purified by silica gel column chromatography ( $\mathrm{PE}: \mathrm{EE}=3: 1)$ to afford $30(78 \mathrm{mg}$, 19\%). ${ }^{1} \mathrm{H}$ NMR (400 MHz, $\left.\mathrm{CDCl}_{3}\right): \delta 7.59(\mathrm{~d}, J=7.9 \mathrm{~Hz}, 1 H$ ), $7.30(\mathrm{~d}, J=8.2 \mathrm{~Hz}, 1 H), 7.24-7.18(\mathrm{~m}, 1 H), 7.14-7.04(\mathrm{~m}, 1 H)$, $6.96(\mathrm{~s}, 1 H), 4.10(\mathrm{t}, J=6.9 \mathrm{~Hz}, 2 H), 3.87(\mathrm{t}, J=6.4 \mathrm{~Hz}, 2 H)$, $3.35(\mathrm{t}, J=6.5 \mathrm{~Hz}, 2 H), 3.00(\mathrm{t}, J=6.4 \mathrm{~Hz}, 2 H), 2.05-1.94$ $(\mathrm{m}, 2 H), 1.89-1.78(\mathrm{~m}, 2 H)$.

4.2.17. 3-[1-(4-Bromobutyl)-1H-indol-3-yl]propan-1-ol (31). The procedure described for the synthesis of 30 was applied to alcohol 29 (1.20 g, $6.86 \mathrm{mmol})$, 1,4-dibromobutane (4.38 g, $20.6 \mathrm{mmol}$ ), and $\mathrm{NaH}$ (329 $\mathrm{mg}, 13.7 \mathrm{mmol})$ to afford 31 (728 mg, 34\%). ${ }^{1} \mathrm{H}$ NMR (400 MHz, $\left.\mathrm{CDCl}_{3}\right): \delta 7.60(\mathrm{~d}, J=7.9 \mathrm{~Hz}$, $1 H), 7.29(\mathrm{~d}, J=8.2 \mathrm{~Hz}, 1 H), 7.25-7.14(\mathrm{~m}, 1 H), 7.12-7.07(\mathrm{~m}, 1 H)$, $6.87(\mathrm{~s}, 1 H), 4.08(\mathrm{t}, J=6.8 \mathrm{~Hz}, 2 H), 3.70(\mathrm{t}, J=6.4 \mathrm{~Hz}, 2 H)$, $3.35(\mathrm{t}, J=6.5 \mathrm{~Hz}, 2 H), 2.84(\mathrm{t}, J=7.5 \mathrm{~Hz}, 2 H), 2.03-1.90(\mathrm{~m}, 4 H)$, 1.86-1.77 (m, 2H).

4.2.18. 1-(4-Bromobutyl)-3-(2-fluoroethyl)-1H-indole (32). Under argon atmosphere $\left(-78{ }^{\circ} \mathrm{C}\right)$, a solution of DAST (352 $\mathrm{mg}, 2.18 \mathrm{mmol})$ in $\mathrm{CH}_{2} \mathrm{Cl}_{2}(20 \mathrm{~mL})$ was added into a solution of $30(538 \mathrm{mg}, 1.82 \mathrm{mmol})$ in $\mathrm{CH}_{2} \mathrm{Cl}_{2}(20 \mathrm{~mL})$. The mixture was stirred for $2 \mathrm{~h}$, followed by addition of saturated sodium hyposulfite to quench the reaction. The crude product was extracted with ethyl acetate, dried with anhydrous $\mathrm{MgSO}_{4}$, and purified by silica gel column chromatography $(\mathrm{PE}: \mathrm{EE}=$ $10: 1)$ to afford $32(315 \mathrm{mg}, 58 \%) .{ }^{1} \mathrm{H}$ NMR (400 $\mathrm{MHz}, \mathrm{CDCl}_{3}$ ): $\delta 7.58(\mathrm{~d}, J=7.9 \mathrm{~Hz}, 1 H), 7.30(\mathrm{~d}, J=8.2 \mathrm{~Hz}, 1 H), 7.23-7.18$ (m, $1 H$ ), 7.14-7.08 (m, $1 H), 6.96(\mathrm{~s}, 1 H), 4.67(\mathrm{dt}, J=47.2,6.7 \mathrm{~Hz}$, $2 H), 4.11(\mathrm{t}, J=6.9 \mathrm{~Hz}, 2 H), 3.36(\mathrm{t}, J=6.5 \mathrm{~Hz}, 2 H), 3.15(\mathrm{dt}, J=$ 22.2, 6.5 Hz, 2H), 2.03-1.95 (m, 2H), 1.90-1.79 (m, 2H).

4.2.19. 1-(4-Bromobutyl)-3-(3-fluoropropyl)-1H-indole (33). The procedure described for the synthesis of 32 was applied to DAST (205 mg, $1.28 \mathrm{mmol}$ ) and 31 (360 $\mathrm{mg}, 1.16 \mathrm{mmol})$ to afford 33 (315 mg, 87\%). ${ }^{1} \mathrm{H}$ NMR (400 $\mathrm{MHz}, \mathrm{CDCl}_{3}$ ): $\delta 7.63$ $(\mathrm{d}, J=7.9 \mathrm{~Hz}, 1 H), 7.33(\mathrm{~d}, J=8.2 \mathrm{~Hz}, 1 \mathrm{H}), 7.28-7.22(\mathrm{~m}, 1 H)$, 7.17-7.11 (m, $1 H), 6.92(\mathrm{~s}, 1 H), 4.53(\mathrm{dt}, J=47.3,5.9 \mathrm{~Hz}, 2 H)$, $4.12(\mathrm{t}, J=6.8 \mathrm{~Hz}, 2 H), 3.38(\mathrm{t}, J=6.5 \mathrm{~Hz}, 2 H), 2.92(\mathrm{t}, J=7.5 \mathrm{~Hz}$, $2 H)$, 2.19-2.05 (m, 2H), 2.04-1.96 (m, 2H), 1.90-1.81 (m, 2H).

4.2.20. 2-\{4-[3-(2-Fluoroethyl)-1H-indol-1-yl]butyl\}-6,7dimethoxy-1,2,3,4-tetrahydroisoquinoline (3a). The procedure described for the synthesis of 3 a was applied to $32(78 \mathrm{mg}$, $0.26 \mathrm{mmol}$ ), 16 (76 mg, $0.39 \mathrm{mmol}$ ), and $\mathrm{K}_{2} \mathrm{CO}_{3}(54 \mathrm{mg}, 0.39$ $\mathrm{mmol}$ ) to afford $3 \mathrm{a}(46 \mathrm{mg}, 43 \%) .{ }^{1} \mathrm{H}$ NMR (400 $\mathrm{MHz}, \mathrm{CDCl}_{3}$ ): $\delta 7.57(\mathrm{~d}, J=7.9 \mathrm{~Hz}, 1 H), 7.31(\mathrm{~d}, J=8.2 \mathrm{~Hz}, 1 H), 7.21-7.16$ $(\mathrm{m}, 1 H), 7.12-7.07(\mathrm{~m}, 1 H), 6.98(\mathrm{~s}, 1 H), 6.57(\mathrm{~s}, 1 H), 6.48$ $(\mathrm{s}, 1 H), 4.66(\mathrm{dt}, J=47.2,6.7 \mathrm{~Hz}, 2 H), 4.11(\mathrm{t}, J=7.0 \mathrm{~Hz}, 2 H), 3.82$ (s, $3 H), 3.81(\mathrm{~s}, 3 H), 3.48(\mathrm{~s}, 2 H), 3.15(\mathrm{dt}, J=22.1,6.7 \mathrm{~Hz}, 2 H)$, $2.78(\mathrm{t}, J=5.7 \mathrm{~Hz}, 2 H), 2.64(\mathrm{t}, J=5.8 \mathrm{~Hz}, 2 H), 2.48(\mathrm{t}, J=5.8 \mathrm{~Hz}$, $2 H)$, 1.94-1.84 (m, 2H), 1.66-1.54 (m, 2H); ${ }^{13} \mathrm{C}$ NMR (100 MHz, $\left.\mathrm{CDCl}_{3}\right): \delta 147.7,147.4,136.4,128.1,126.7,126.4,126.3,121.7$, 119.1, 119.0, 111.6, 109.8, 109.8, 109.7, 84.1, 57.9, 56.1, 56.0, 51.3, 46.3, 28.9, 28.4, 26.9, 26.6, 24.9; ${ }^{19} \mathrm{~F} \mathrm{NMR} \mathrm{(376} \mathrm{MHz,} \mathrm{CDCl}_{3}$ ): $\delta$-213.3. MS (ESI $\left.{ }^{+}\right): m / z=$ calcd. for $\mathrm{C}_{25} \mathrm{H}_{31} \mathrm{FN}_{2} \mathrm{O}_{2}[\mathrm{M}+\mathrm{H}]^{+}$411.2, found 411.1; HRMS (EI): $\mathrm{m} / z$ calcd. for $\mathrm{C}_{25} \mathrm{H}_{31} \mathrm{FN}_{2} \mathrm{O}_{2}[\mathrm{M}+\mathrm{H}]^{+}$ 411.2448, found 411.2443; purity (HPLC): 95\%.

4.2.21. 2-\{4-[3-(3-Fluoropropyl)-1H-indol-1-yl]butyl $\}-6,7-$ dimethoxy-1,2,3,4-tetrahydroisoquinoline $(3 \mathrm{~b})$. The procedure described for the synthesis of 3a was applied to $33(113 \mathrm{mg}$, $0.36 \mathrm{mmol}$ ), 16 (73 $\mathrm{mg}, 0.38 \mathrm{mmol}$ ), and $\mathrm{K}_{2} \mathrm{CO}_{3}$ (60 mg, 0.43 $\mathrm{mmol}$ ) to afford $3 \mathrm{~b}(55 \mathrm{mg}, 36 \%) .{ }^{1} \mathrm{H}$ NMR (400 $\mathrm{MHz}, \mathrm{CDCl}_{3}$ ): $\delta 7.60(\mathrm{~d}, J=7.8 \mathrm{~Hz}, 1 H), 7.33(\mathrm{~d}, J=8.2 \mathrm{~Hz}, 1 H), 7.20(\mathrm{t}, J=$ $7.6 \mathrm{~Hz}, 1 H), 7.11(\mathrm{t}, J=7.4 \mathrm{~Hz}, 1 H), 6.93(\mathrm{~s}, 1 H), 6.60(\mathrm{~s}, 1 H)$, $6.51(\mathrm{~s}, 1 H), 4.51(\mathrm{dt}, J=47.4,5.9 \mathrm{~Hz}, 2 H), 4.13(\mathrm{t}, J=7.0 \mathrm{~Hz}$, $2 H), 3.85(\mathrm{~s}, 3 H), 3.84(\mathrm{~s}, 3 H), 3.51(\mathrm{~s}, 2 H), 2.90(\mathrm{t}, J=7.4 \mathrm{~Hz}$, $2 H), 2.81(\mathrm{t}, J=5.6 \mathrm{~Hz}, 2 H), 2.67(\mathrm{t}, J=5.8 \mathrm{~Hz}, 2 H), 2.51(\mathrm{t}, J=$ $7.3 \mathrm{~Hz}, 2 H), 2.18-2.02(\mathrm{~m}, 2 H), 1.97-1.88$ (m, 2H), 1.67-1.57 $(\mathrm{m}, 2 H) ;{ }^{13} \mathrm{C}$ NMR $\left(100 \mathrm{MHz}, \mathrm{CDCl}_{3}\right): \delta 147.7,147.4,136.6$, $128.1,126.8,126.4,125.6,121.6,119.2,118.8,113.9,111.6$, 109.7, 109.6, 83.7, 57.9, 56.1, 56.0, 51.3, 46.2, 31.3, 31.2, 28.9, 28.4, 24.9, 20.8; ${ }^{19} \mathrm{~F}$ NMR (376 $\mathrm{MHz}, \mathrm{CDCl}_{3}$ ): $\delta-220.5$; MS (ESI $\left.{ }^{+}\right): m / z=$ calcd. for $\mathrm{C}_{26} \mathrm{H}_{33} \mathrm{FN}_{2} \mathrm{O}_{2}[\mathrm{M}+\mathrm{H}]^{+} 425.3$, found 425.0; HRMS (EI): $m / z$ calcd. for $\mathrm{C}_{26} \mathrm{H}_{33} \mathrm{FN}_{2} \mathrm{O}_{2}[\mathrm{M}+\mathrm{H}]^{+}$ 425.2604, found 425.2601. Anal. calcd. for $\mathrm{C}_{26} \mathrm{H}_{33} \mathrm{FN}_{2} \mathrm{O}_{2} \cdot 3 / 4 \mathrm{H}_{2} \mathrm{O}$ (438.06): C 71.29, N 6.39, H 7.94; found: C 71.24, N 6.57, H 7.63.

4.2.22. $\quad 1^{\prime}-\{4-[3-(2-F l u o r o e t h y l)-1 H$-indol-1-yl]butyl $\}-3 H$ spiro[isobenzofuran-1,4'-piperidine] (3c). To a solution of 32 (70 mg, $0.24 \mathrm{mmol})$ in $\mathrm{CH}_{3} \mathrm{CN}(20 \mathrm{~mL}), 25$ (45 mg, $\left.0.24 \mathrm{mmol}\right)$ and $\mathrm{K}_{2} \mathrm{CO}_{3}$ (40 mg, $0.29 \mathrm{mmol}$ ) were added. The mixture was stirred at $80{ }^{\circ} \mathrm{C}$ for $4 \mathrm{~h}$. After cooling and filtration, the solvent 
was removed under reduced pressure. The residue was purified by silica gel column chromatography ( $\mathrm{PE}: \mathrm{EE}=1: 5)$ to afford 3c (40 mg, 41\%). ${ }^{1} \mathrm{H}$ NMR (400 MHz, $\mathrm{CDCl}_{3}$ ): $\delta 7.58$ (d, $J=7.9$ $\mathrm{Hz}, 1 H), 7.33$ (d, $J=8.2 \mathrm{~Hz}, 1 H), 7.29-7.16$ (m, 4H), 7.15-7.07 (m, 2H), $6.99(\mathrm{~s}, 1 H), 5.06(\mathrm{~s}, 2 H), 4.66(\mathrm{dt}, J=47.2,6.7 \mathrm{~Hz}, 2 H)$, $4.10(\mathrm{t}, J=7.1 \mathrm{~Hz}, 2 H), 3.16(\mathrm{dt}, J=21.9,6.7 \mathrm{~Hz}, 2 H), 2.81(\mathrm{~d}, J=$ $11.0 \mathrm{~Hz}, 2 H), 2.47-2.29(\mathrm{~m}, 4 H), 2.03-1.81(\mathrm{~m}, 4 H), 1.75(\mathrm{~d}, J=$ $12.5 \mathrm{~Hz}, 2 H)$, 1.62-1.52 (m, 2H); ${ }^{13} \mathrm{C} \mathrm{NMR}\left(100 \mathrm{MHz}, \mathrm{CDCl}_{3}\right): \delta$ $145.8,139.1,136.4,128.1,127.8,127.6,126.3,121.8,121.3$, 121.0, 119.1, 109.8, 109.8, 109.7, 84.9, 83.3, 71.0, 58.6, 50.4 (2C), 46.4, 36.8 (2C), 28.6, 26.8, 24.8; $\left.{ }^{19} \mathrm{~F} \mathrm{NMR} \mathrm{(376} \mathrm{MHz}, \mathrm{CDCl}_{3}\right): \delta-$ 213.2; $\mathrm{MS}\left(\mathrm{ESI}^{+}\right): m / z=$ calcd. for $\mathrm{C}_{26} \mathrm{H}_{31} \mathrm{FN}_{2} \mathrm{O}[\mathrm{M}+\mathrm{H}]^{+}$407.2, found 407.1; HRMS (EI): $m / z$ calcd. for $\mathrm{C}_{26} \mathrm{H}_{31} \mathrm{FN}_{2} \mathrm{O}[\mathrm{M}+\mathrm{H}]^{+}$ 407.2499, found 407.2501; purity (HPLC): 96\%.

4.2.23. 4-[1-(4-Iodophenyl)-1H-indol-3-yl]butan-1-ol (34). Compound 19 (595 mg, $3.14 \mathrm{mmol}$ ), 1,4-diiodobenzene (780 $\mathrm{mg}, 2.36 \mathrm{mmol}), \mathrm{K}_{2} \mathrm{CO}_{3}(3.12 \mathrm{~g}, 23.6 \mathrm{mmol})$, a catalytic amount of copper powder, and 18-crown-6 were added into $25 \mathrm{~mL}$ of DMF. The mixture was stirred at $120{ }^{\circ} \mathrm{C}$ for $5 \mathrm{~h}$. After cooling and filtration, the crude product was extracted with ethyl acetate and washed with $1 \mathrm{M} \mathrm{HCl}$ and saturated $\mathrm{NaCl}$ solution. The organic layer was dried over $\mathrm{MgSO}_{4}$, and the solvent was removed under reduced pressure. The residue was purified by silica gel column chromatography (PE: EE = $4: 1)$ to afford 34 (208 mg, 23\%). ${ }^{1} \mathrm{H}$ NMR (400 $\mathrm{MHz}, \mathrm{CDCl}_{3}$ ): $\delta 7.76-7.72(\mathrm{~m}, 2 H), 7.57(\mathrm{t}, J=7.6 \mathrm{~Hz}, 1 H), 7.46(\mathrm{t}, J=8.2 \mathrm{~Hz}$, $1 H), 7.18-7.08(\mathrm{~m}, 4 H), 7.03(\mathrm{~s}, 1 H), 3.64(\mathrm{t}, J=6.5 \mathrm{~Hz}, 2 H)$, $2.76(\mathrm{t}, J=7.4 \mathrm{~Hz}, 2 H), 1.80-1.73(\mathrm{~m}, 2 H), 1.67-1.60(\mathrm{~m}, 2 H)$; ${ }^{13} \mathrm{C}$ NMR (100 MHz, $\left.\mathrm{CDCl}_{3}\right): \delta 139.6,138.6$ (2C), 135.8, 129.2, 125.7, 124.6, 122.7 (2C), 120.1, 119.4, 118.3, 110.3, 90.0, 62.9, 32.6, 26.1, 24.8; $\mathrm{MS}\left(\mathrm{ESI}^{+}\right): m / z=$ calcd. for $\mathrm{C}_{18} \mathrm{H}_{18} \mathrm{INO}[\mathrm{M}+\mathrm{H}]^{+}$ 392.0, found 392.2.

4.2.24. 3-(4-Bromobutyl)-1-(4-iodophenyl)-1H-indole (35). Under argon atmosphere and ice bath, $\operatorname{PBr}_{3}(192 \mathrm{mg}, 0.71$ mmol) was added to a solution of $34(550 \mathrm{mg}, 1.41 \mathrm{mmol})$ in $\mathrm{CH}_{2} \mathrm{Cl}_{2}$. The mixture was stirred at room temperature for $2 \mathrm{~h}$, followed by addition of saturated $\mathrm{NaHCO}_{3}$ solution to quench the reaction. The crude product was extracted with ethyl acetate, dried with anhydrous $\mathrm{MgSO}_{4}$, and purified by silica gel column chromatography ( $\mathrm{PE}: \mathrm{EE}=4: 1)$ to afford $35(187 \mathrm{mg}$, 58\%). ${ }^{1} \mathrm{H}$ NMR (400 MHz, $\left.\mathrm{CDCl}_{3}\right): \delta 7.81(\mathrm{t}, J=8.2 \mathrm{~Hz}, 2 H)$, $7.64(\mathrm{t}, J=7.0 \mathrm{~Hz}, 1 H), 7.52(\mathrm{t}, J=8.1 \mathrm{~Hz}, 1 H), 7.26-7.16(\mathrm{~m}$, $4 H), 7.10(\mathrm{~s}, 1 H), 3.47(\mathrm{t}, J=6.5 \mathrm{~Hz}, 2 H), 2.83(\mathrm{t}, J=7.24 \mathrm{~Hz}$, $2 H)$, 2.03-1.98 (m, 2H), 1.96-1.91 (m, 2H); ${ }^{13} \mathrm{C}$ NMR (100 $\mathrm{MHz}, \mathrm{CDCl}_{3}$ ): $\delta 139.6,138.6$ (2C), 135.8, 129.1, 125.7, 124.6, 122.7 (2C), 120.2, 119.4, 117.8, 110.4, 90.0, 33.8, 32.5, 28.4, 24.2; $\mathrm{MS}\left(\mathrm{ESI}^{+}\right): \mathrm{m} / z=$ calcd. for $\mathrm{C}_{18} \mathrm{H}_{17} \mathrm{BrIN}[\mathrm{M}+\mathrm{H}]^{+}$454.0, found 453.9 .

4.2.25. 1-\{4-[1-(4-Iodophenyl)-1H-indol-3-yl] butyl\}-4phenylpiperidine-4-carbonitrile (4). Compound 35 (163 mg, $0.36 \mathrm{mmol}$ ), 4-phenylpiperidine-4-carbonitrile (18) $(147 \mathrm{mg}$, $0.72 \mathrm{mmol}$ ), $\mathrm{K}_{2} \mathrm{CO}_{3}$ (496 g, $3.60 \mathrm{mmol}$ ), and $\mathrm{KI}$ (64 mg, 0.39 mmol) were added into $\mathrm{CH}_{3} \mathrm{CN}$ solution. The mixture was stirred at $80{ }^{\circ} \mathrm{C}$ for $4 \mathrm{~h}$. After cooling and filtration, the solvent was removed under reduced pressure. The residue was purified by silica gel column chromatography (PE $: \mathrm{EE}=2: 1$ ) to afford 4 (99 mg, 49\%). ${ }^{1} \mathrm{H}$ NMR (400 $\left.\mathrm{MHz}, \mathrm{CDCl}_{3}\right): \delta 7.74-$ $7.71(\mathrm{~m}, 2 H), 7.57$ (d, $J=3.8 \mathrm{~Hz}, 1 H), 7.46-7.41(\mathrm{~m}, 3 H), 7.34$ $(\mathrm{t}, J=7.2 \mathrm{~Hz}, 2 H), 7.30-7.23(\mathrm{~m}, 2 H), 7.19-7.17(\mathrm{~m}, 2 H) 7.12-$ $7.08(\mathrm{~m}, 1 H), 7.03(\mathrm{~s}, 1 H), 2.98(\mathrm{~d}, J=11.96 \mathrm{~Hz}, 2 H), 2.76(\mathrm{t}, J=$ $7.36 \mathrm{~Hz}, 2 H), 2.47-2.38(\mathrm{~m}, 4 H), 2.04(\mathrm{~s}, 4 H), 1.74-1.68(\mathrm{~m}, 2 H)$, 1.61-1.58 (m, 2H); ${ }^{13} \mathrm{C}$ NMR (100 MHz, $\left.\mathrm{CDCl}_{3}\right): \delta$ 139.2, 138.6 (2C), 137.6, 134.8, 128.2 (2C), 128.0, 127.1, 124.7 (2C), 124.6, 123.5, 121.7 (2C), 120.8, 119.1, 118.4, 117.3, 109.3, 88.9, 57.3, 49.8 (2C), 41.8, 35.4 (2C), 26.8, 25.7, 23.9; MS (ESI ${ }^{+}$: $\mathrm{m} / \mathrm{z}=$ calcd. for $\mathrm{C}_{30} \mathrm{H}_{30} \mathrm{IN}_{3}[\mathrm{M}+\mathrm{H}]^{+}$560.1, found 560.1. Anal. calcd. for $\mathrm{C}_{30} \mathrm{H}_{30} \mathrm{IN}_{3} \cdot \mathrm{HCl} \cdot 1 / 2 \mathrm{H}_{2} \mathrm{O}(604.95)$ : C 59.56, N 6.95, H 5.33; found: C 59.76, N 6.82, H 5.17.

4.2.26. 2-\{4-[1-(4-Fluorophenyl)-1H-indol-3-yl]butyl $\}-6,7-$ dimethoxy-1,2,3,4-tetrahydroisoquinoline (5). Compound 36 (279 mg, 1.08 mmol), 6,7-dimethoxy-1,2,3,4-tetrahydroisoquinoline hydrochloride $(153 \mathrm{mg}, 0.67 \mathrm{mmol})$, and $\mathrm{K}_{2} \mathrm{CO}_{3}(220 \mathrm{mg}, 1.59 \mathrm{mmol})$ were added into $25 \mathrm{~mL}$ of $\mathrm{CH}_{3} \mathrm{CN}$. The mixture was stirred at $80{ }^{\circ} \mathrm{C}$ for $4 \mathrm{~h}$. After the solvent was removed under reduced pressure, the residue was purified by silica gel column chromatography $\left(\mathrm{CH}_{2} \mathrm{Cl}_{2}\right.$ : $\mathrm{MeOH}=20: 1)$ to afford $5(153 \mathrm{mg}, 62 \%) .{ }^{1} \mathrm{H}$ NMR (400 MHz, $\left.\mathrm{CDCl}_{3}\right): \delta 7.98-7.90(\mathrm{~m}, 2 H), 7.09-7.02(\mathrm{~m}, 2 H), 6.54(\mathrm{~s}, 1 H)$, $6.47(\mathrm{~s}, 1 H), 3.80(\mathrm{~s}, 3 H), 3.79(\mathrm{~s}, 3 H), 3.52(\mathrm{~s}, 2 H), 2.96(\mathrm{t}, J=$ $7.2 \mathrm{~Hz}, 2 H), 2.77(\mathrm{t}, J=5.8 \mathrm{~Hz}, 2 H), 2.67(\mathrm{t}, J=5.9 \mathrm{~Hz}, 2 H)$, $2.52(\mathrm{t}, J=7.3 \mathrm{~Hz}, 2 H), 1.82-1.71(\mathrm{~m}, 2 H), 1.71-1.61(\mathrm{~m}, 2 H)$; ${ }^{13} \mathrm{C}$ NMR (101 MHz, $\left.\mathrm{CDCl}_{3}\right): \delta$ 198.6, 165.5, 147.5, 147.2, 133.3, 130.6 (2C), 126.5, 126.1, 115.6 (2C), 111.3, 109.4, 57.8, 55.9, 55.9, 55.7, 50.9, 38.2, 28.6, 26.6, 22.3; ${ }^{19} \mathrm{~F}$ NMR (376 $\left.\mathrm{MHz}, \mathrm{CDCl}_{3}\right): \delta-106.7 ; \mathrm{MS}\left(\mathrm{ESI}^{+}\right): \mathrm{m} / z=$ calcd. for $\mathrm{C}_{22} \mathrm{H}_{26} \mathrm{FNO}_{3}[\mathrm{M}+\mathrm{H}]^{+} 372.2$, found 372.2; HRMS (EI): $\mathrm{m} / \mathrm{z}$ calcd. for $\mathrm{C}_{22} \mathrm{H}_{26} \mathrm{FNO}_{3}[\mathrm{M}+\mathrm{H}]^{+} 372.1975$, found 372.1972. Anal. calcd. for $\mathrm{C}_{22} \mathrm{H}_{26} \mathrm{FNO}_{3} \cdot 3 / 4 \mathrm{H}_{2} \mathrm{O}$ (384.96): C 68.64, N 3.64, H 7.20; found: C 68.74, N 3.92, H 6.82.

\subsection{In vitro radioligand competition studies}

Competition assays of $\sigma_{1}$ and $\sigma_{2}$ receptors were performed as previous reported in the literature..$^{28,29}$ The detailed procedures are provided in the ESI.

\subsection{Cell culture and antiproliferative assay}

The cancer cell lines MCF7 (human mammary carcinoma), DU145 (human prostate carcinoma) and C6 (rat glioma) were routinely cultured in Beijing Normal University. The MTT assay was used to determine the antiproliferative activity of compounds $\mathbf{1 a}$ and $\mathbf{1 b}$ and siramesine in these cell lines as described previously. ${ }^{30,31}$ The procedures are shown in the ESI.†

\subsection{Flow cytometry cell cycle analysis}

1a, 1b and siramesine were cultured in DU145 cell line for $24 \mathrm{~h}$ to examine cell cycle arrest as described previously. ${ }^{32}$ The detailed procedures are shown in the ESI. $\dagger$ 


\section{Acknowledgements}

The excellent technical assistance of Aline Morgenegg, Catharina Heinig, Tina Spalholz and Peggy Wecke is greatly acknowledged. This work was supported by the National Natural Science Foundation of China (No. 21471019) and supported in part (C.N., J.P., T.K., and J.S.) by the Helmholtz Association within Helmholtz-Portfolio Topic "Technologie und Medizin - Multimodale Bildgebung zur Aufklärung des In-vivo-Verhaltens von polymeren Biomaterialien". Fang Xie acknowledges the financial support from China Scholarship Council (CSC) for his study in HZDR.

\section{Notes and references}

1 R. Quirion, W. D. Bowen, Y. Itzhak, J. L. Junien, J. M. Musacchio, R. B. Rothman, T. P. Su, S. W. Tam and D. P. Taylor, Trends Pharmacol. Sci., 1992, 13, 85-86.

2 M. Hanner, F. F. Moebius, A. Flandorfer, H. G. Knaus, J. Striessnig, E. Kempner and H. Glossmann, Proc. Natl. Acad. Sci. U. S. A., 1996, 93, 8072-8077.

3 E. Aydar, C. P. Palmer, V. A. Klyachko and M. B. Jackson, Neuron, 2002, 34, 399-410.

4 T. Hayashi and T. P. Su, Cell, 2007, 131, 596-610.

5 T. P. Su, T. Hayashi, T. Maurice, S. Buch and A. E. Ruoho, Trends Pharmacol. Sci., 2010, 31, 557-566.

6 J. Xu, C. Zeng, W. Chu, F. Pan, J. M. Rothfuss, F. Zhang, Z. Tu, D. Zhou, D. Zeng, S. Vangveravong, F. Johnston, D. Spitzer, K. C. Chang, R. S. Hotchkiss, W. G. Hawkins, K. T. Wheeler and R. H. Mach, Nat. Commun., 2011, 2, 380.

7 B. J. Vilner, C. S. John and W. D. Bowen, Cancer Res., 1995, 55, 408-413.

8 A. Van Waarde, A. A. Rybczynska, N. K. Ramakrishnan, K. Ishiwata, P. H. Elsinga and R. A. J. O. Dierckx, Curr. Pharm. Des., 2010, 16, 3519-3537.

9 I. Al-Nabulsi, R. H. Mach, L. M. Wang, C. A. Wallen, P. C. Keng, K. Sten, S. R. Childers and K. T. Wheeler, Br. J. Cancer, 1999, 81, 925-933.

10 K. T. Wheeler, L. M. Wang, C. A. Wallen, S. R. Childers, J. M. Cline, P. C. Keng and R. H. Mach, Br. J. Cancer, 2009, 82, 1223-1232.

11 R. H. Mach, C. R. Smith, I. Al-Nabulsi, B. R. Whirrett, S. R. Childers and K. T. Wheeler, Cancer Res., 1997, 57, 156-161.

12 M. S. Ostenfeld, N. Fehrenbacher, M. Høyer-Hansen, C. Thomsen, T. Farkas and M. Jäättelä, Cancer Res., 2005, 65, 8975-8983.

13 L. Groth-Pedersen, M. S. Ostenfeld, M. Høyer-Hansen, J. Nylandsted and M. Jäättelä, Cancer Res., 2007, 67, 2217-2225.
14 M. J. Parry, J.-M. I. Alakoskela, H. Khandelia, S. A. Kumar, M. Jäättelä, A. K. Mahalka and P. K. J. Kinnunen, J. Am. Chem. Soc., 2008, 130, 12953-12960.

15 C. Zeng, J. Rothfuss, J. Zhang, W. Chu, S. Vangveravong, Z. Tu, F. Pan, K. C. Chang, R. Hotchkiss and R. H. Mach, Br. J. Cancer, 2012, 106, 693-701.

16 R. H. Mach, C. Zeng and W. G. Hawkins, J. Med. Chem., 2013, 56, 7137-7160.

17 C. Abate, R. Perrone and F. Berardi, Curr. Pharm. Des., 2012, 18, 938-949.

18 M. H. Cesen, U. Repnik, V. Turk and B. Turk, Cell Death Dis., 2013, 4, e818.

19 Y. Li, H. Jia, W. Deuther-Conrad, P. Brust, J. Steinbach and B. Liu, He Huaxue Yu Fangshe Huaxue, 2010, 32, 99-105.

20 M. H. Herth, V. Kramer and F. Rösch, J. Labelled Compd. Radiopharm., 2009, 52, 201-207.

21 H. Kubota, M. Fujii, K. Ikeda, M. Takeuchi, T. Shibanuma and Y. Isomura, Chem. Pharm. Bull., 1998, 46, 351-354.

22 H. Shao, X. Chen, Z. Wang and P. Lu, J. Lumin., 2007, 127, 349-354.

23 C. Fan, H. Jia, W. Deuther-Conrad, P. Brust, J. Steinbach and B. Liu, Sci. China, Ser. B: Chem., 2006, 49, 169-176.

24 J. Perregaard, E. K. Moltzen, E. Meier and C. Sanchez, J. Med. Chem., 1995, 38, 1998-2008.

25 M. Niso, C. Abate, M. Contino, S. Ferorelli, A. Azzariti, R. Perrone, N. A. Colabufo and F. Berardi, ChemMedChem, 2013, 8, 2026-2035.

26 K.-H. Fan, J. R. Lever and S. Z. Lever, Bioorg. Med. Chem., 2011, 19, 1852-1859.

27 Z. Tu, J. Xu, L. A. Jones, S. Li, C. Dumstorff, S. Vangveravong, D. L. Chen, K. T. Wheeler, M. J. Welch and R. H. Mach, J. Med. Chem., 2007, 50, 3194-3204.

28 Y. Li, X. Wang, J. Zhang, W. Deuther-Conrad, F. Xie, X. Zhang, J. Liu, J. Qiao, M. Cui, J. Steinbach, P. Brust, B. Liu and H. Jia, J. Med. Chem., 2013, 56, 3478-3491.

29 X. Wang, Y. Li, W. Deuther-Conrad, F. Xie, X. Chen, M.-C. Cui, X.-J. Zhang, J.-M. Zhang, J. Steinbach, P. Brust, B.-L. Liu and H.-M. Jia, Bioorg. Med. Chem., 2013, 21, 215-222.

30 C. Mamat, B. Mosch, C. Neuber, M. Köckerling, R. Bergmann and J. Pietzsch, ChemMedChem, 2012, 7, 1991-2003.

31 B. Mosch, K. Mueller, J. Steinbach and J. Pietzsch, Int. J. Radiat. Biol., 2009, 85, 1002-1012.

32 S. Li, X. Wang, Y. He, M. Zhao, Y. Chen, J. Xu, M. Feng, J. Chang, H. Ning and C. Qi, Eur. J. Med. Chem., 2013, 67, 293-301. 